\title{
1 Buried Solutions: How Maya urban life substantiates soil connectivity
}

2 Authors: Daniel L. Evans ${ }^{a^{*}}$, Benjamin N. Vis ${ }^{b}$, Nicholas P. Dunning ${ }^{c}$, Elizabeth

3 Graham $^{\mathrm{d}}$, and Christian Isendahle

4 aLancaster Environment Centre, Lancaster University, Lancaster, Lancashire, UK;

$5 \quad$ bentre of African Studies, Department of Middle Eastern Studies, University of West

6 Bohemia, Czech Republic; 'Department of Geography and GIS, University of

7 Cincinnati, Cincinnati, Ohio, USA; dInstitute of Archaeology, University College

8 London, London, UK; ' $D$ epartment of Historical Studies, University of Gothenburg,

9 Gothenburg, Sweden

$10 \quad{ }^{*}$ Corresponding author. d.evans3@lancaster.ac.uk

11 Keywords: Soil connectivity; urban soil security; soil sealing; Maya urbanism;

12 applied archaeology; urban sustainability.

13 Abbreviations: ADE (Amazonian Dark Earths); MDE (Maya Dark Earths) 
Abstract:

Soils are a pivot of sustainable development. Yet, urban planning decisions persist in compromising the usability of the urban soils resource. Urban land cover expansion to accommodate an increasing population results in soil sealing. Concealment of and physical obstructions to soils prevent urban populations from engaging with their soil dependency. The concept of soil connectivity recognises that nurturing mutually beneficial soil-society relations is an essential dimension for achieving soil security. The concentrated populations of urban environments acutely require productive soilsociety relations and offer the greatest potential for enhancing soil connectivity. Soil connectivity remains notably under-researched, however, resulting in deficient evidence to substantiate exactly how soil connectivity can contribute to sustaining urban life. The entanglement of soil and urban development has been critical throughout history, but seldom recognised in soil security discourse. We review the manifestation of effective soil connectivity in Precolumbian lowland Maya tropical urbanism. Archaeological evidence reveals, first, that lowland Maya urban settlement patterns largely preserved the availability, proximity, and accessibility of soils in the subdivision and configuration of urban open space. Second, Maya urban life included practices that proactively contributed to the formation of soils by adding to the stock of soils and improving beneficial soil properties of the thin and often nutrient-poor soils resulting from the regionally dominant karstic lithology. Third, a range of Maya landscape modifications and engineering practices enabled the preservation and protection of soils within urban environments. We derive evidencebased insights on an urban tradition that endured for well over two millennia by incorporating intensive soil-society relationships to substantiate the concept of soil 
connectivity. Inspiring urban planning to stimulate soil connectivity through enhancing the engagement with soils in urban life would promote soil security.

\section{Highlights:}

42 1. In urban environments soil connectivity is the principal condition to achieve soil 43 security.

2. Soil-society relationships are implicated in the development of urbanism.

3. Spatial design, soil formation, and soil care in Maya urbanism reveal soil connectivity.

4. Soil connectivity in Maya urban life is promoted by encountering and engaging with soils.

5. Archaeological insights on soil connectivity can benefit planning for urban sustainability. 


\section{Graphical Abstract:}

Archaeological evidence indicates that I effective soil connectivity in cities results

ڤ. not only from stimulating 'knowledge

\% exchange' and 'producer-consumer rela-

tionships', but requires the constant pro-

ज motion of opportunities for 'encounter \&

engagement' with soils

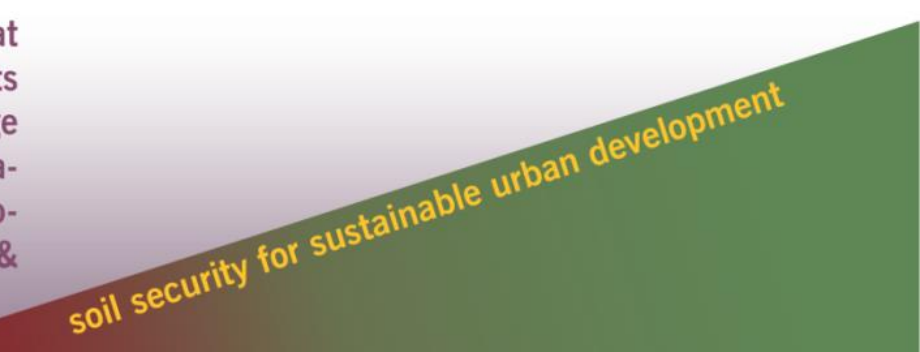

current urban land cover

Soil connectivity

(substantiated)

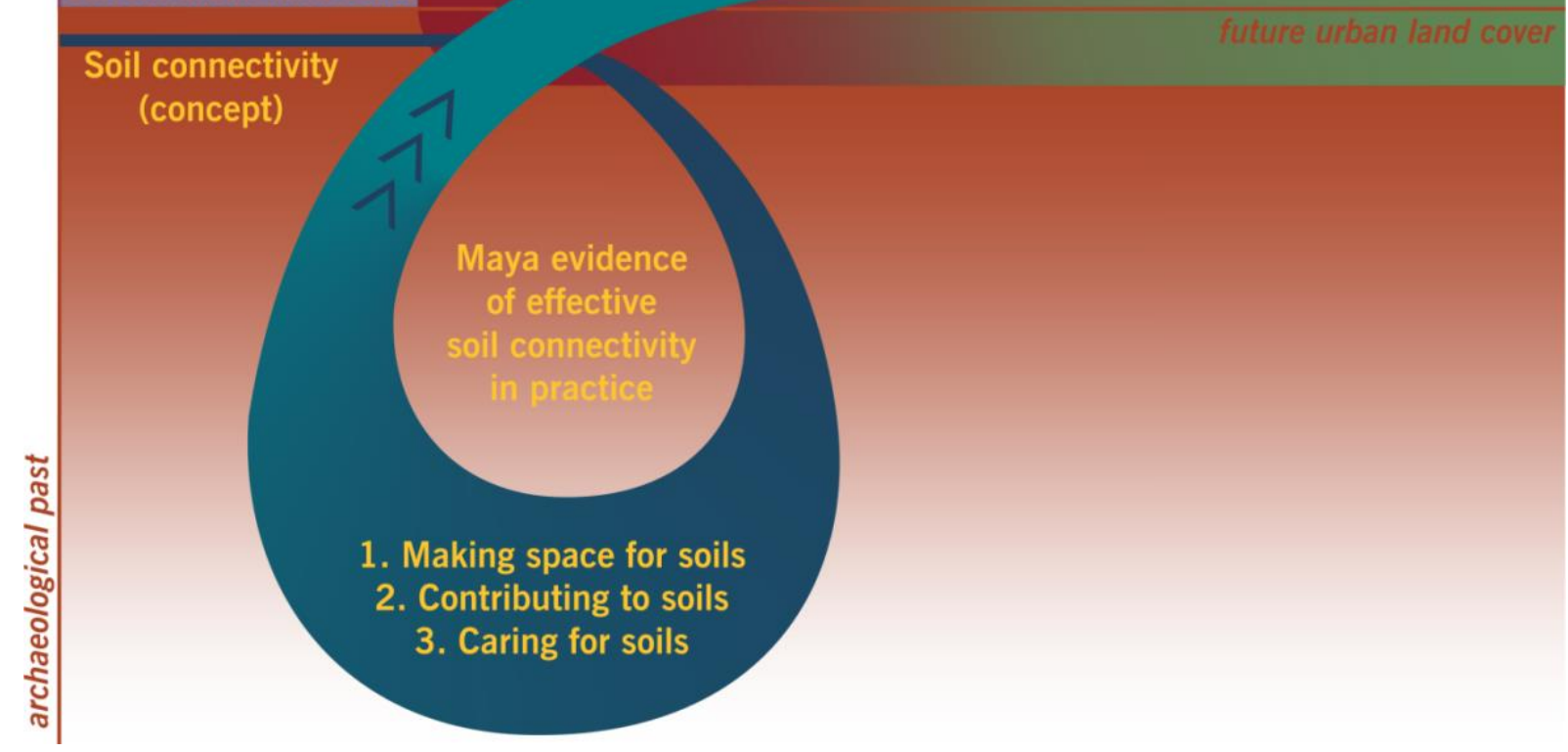




\section{Introduction}

54 Global soils are pivotal to combatting the multiple grand challenges that confront society (McBratney et al., 2014; United Nations, 2015). Soil resources are critical for addressing food, water, and energy security, mitigating the effects of climate change, safeguarding ecosystem diversity, and protecting human health (Blum, 2005). The continuous growth of the world population (Strange, 2015), the environmental consequences of commodity cultures (Hawkins, 2006), and the unequal interdependencies of the global food market (Malm and Hornborg, 2014; Barthel et al., 2019) all exacerbate the demand placed on soils. The land competition caused by this demand on soils is particularly acute in urban environments. Changes to livelihoods and lifestyles, induced by socio-economic development, place great will increase to nearly five billion by 2030 (Seto et al., 2012). To facilitate urbanization, spatial urban encroachment on fertile soils is expected with global urban land cover in 2030 anticipated to nearly triple that seen at the beginning of the $21^{\text {st }}$ century (Seto et al., 2012; FAO, 2015; Bren d'Amour et al., 2017; Barthel et al., 2019). As a result, urban communities face a growing paradox: more land will be required to house more people, yet more land will also be required to sustain them. By living on the land, urban communities obstruct their own sustenance. Resolving the land-use paradox that is exacerbated by further urban growth is therefore an indisputable urban design challenge, yet soil management is seldom a central concern in urban planning and design.

The services provided by soils are ubiquitously embedded in the livelihoods, occupations, businesses, and routines of individuals across both urban and nonurban communities. However, in urban environments the management of soil 
resources usually takes a backseat because developmental priorities are determined on the basis of socio-economic conflicts of interest concerning urban space that result from high local population densities (Barthel et al., 2019). As a result, the usability of urban soils as a resource is at best fragmented; at worst, soils are accessible but contaminated, or simply sealed (Tobias et al., 2018). For instance, in 2006, 2.3\% of the European Union surface area was imperviously sealed (Prokop et al., 2011). Soil sealing refers to the "covering of the soil by a completely or partly impermeable artificial material [. . .] causing an irreversible loss of soil and its biological functions and loss of biodiversity, either directly or indirectly, due to fragmentation of the landscape" (Prokop et al., 2011, p. 15). In urban environments, soil sealing inevitably causes the physical separation of individuals from soils. This carries an emotional charge: what is 'out of sight' is also 'out of mind' (Graham et al., 2021). The loss of quotidian perception of soil, and the ecosystem services it provides, prevents urban inhabitants from having cursory or conscious interactions with soils and detaches them from urban soils as a resource. The distance that is created between urban life and its ecological dependence on soils grows a barrier to engagement which, crucially, leads to both behaviour and developmental decisions in various settings that are detrimental to soils' ability to function.

To enable soils to combat grand societal challenges and achieve soil security in urban environments, the paradox(es) in soil-society relations need to be resolved. Such resolution requires a change in public knowledge about soils and how urban populations regard their engagement with soils. Understanding how individuals or communities can be stimulated to engage proactively with urban soils represents a significant challenge, which corresponds to cross-disciplinary discourse on urban environmental attitudes and care (Gifford and Sussman, 2012; Soga and Gaston, 
2016; Barthel et al., 2018). The importance of soil-society relations only recently started to receive explicit recognition in soil science, in particular, when McBratney et al. (2014) coined the concept of soil connectivity. Before gaining a place on the soil science agenda, soil scientists working in the urban soil domain have tended to focus their efforts on measuring urban soil functions and services (Rawlins et al., 2013; Ferrara et al., 2014) or evaluating urban soil quality and health (Vrščaj et al., 2008; Tresch et al., 2018).

In their assessment of the integral role of soils in global sustainable development, McBratney et al. (2014) propose that soil connectivity is one of five dimensions to achieving soil security. It appears alongside capability (the functions a soil can be expected to perform), condition (the current state of the soil, often discussed in terms of soil 'health'), capital (the soil's stock of physical and biological resources), and codification (the need for public policy and regulation in soil management). While McBratney et al. (2014) do not place the five Cs in a hierarchy of importance, in the context of urban environments, we argue that soil connectivity is the most critical dimension of soil security because societal dependency and engagement directly impact all other dimensions (Bennett et al., 2019). The relationship between communities and soil resources directly influences the capability and condition of soils as well as the resultant capital or use-value of soils, thus requiring governance for the management of soils (codification). Moreover, the concentrated populations in urban environments offer the greatest potential for promoting opportunities for soil connectivity.

McBratney et al. (2014, p. 208) consider two routes for stimulating soil connectivity. First, they propose using public education and devising appropriate sources of information to produce knowledgeable agents capable of lobbying for soil health and 
influencing soil relations through knowledge exchange with those who manage soils.

Second, they propose to cultivate relationships between soil resources and individuals as consumers of soil products to nurture a dialogue between producers and consumers. While we do not contradict the importance of education for soil knowledge exchange and in nurturing the relationship between soil producers and consumers, neither route instates the cursory encounters and the physical engagement of urban populations with the soils in their immediate environment. Indeed, the indirectness of the two routes maintains a distance from soils that provides an excuse for the public to exempt themselves from direct engagement with local soil resources. Meanwhile, circumventing the causes of disconnection reconfiguring urban environments.

Appreciating that urbanisation dominates global development concerns and the pivotal position we ascribe to soil connectivity, it is revealing that McBratney et al. (2014) explicitly recognise that soil connectivity remains under-researched. This perceived lack of attention may partly be explained by how soil connectivity crosses disciplinary boundaries, from the environmental sciences to the social sciences. However, we stress that if soil connectivity is only approached as a field of interest that is particular to the novel urgency of soil security, we risk overlooking that soil connectivity as an extant principle has much deeper roots in practice. Thinking about soil connectivity as a generic principle reveals plentiful valuable evidence of soilgenerated by agriculture eventually supported economies of scale leading to 
reorganisation, which allowed sedentary communities to grow into urban societies (cf. Childe, 1950; Smith et al., 2014). Unsurprisingly, the archaeological record shows that cities historically emerged on or in close association with and proximity to fertile land. When one supplants the misleading notion of urban-rural dichotomies, the dynamic of the emergence of cities exhibits the inextricable link between services provided by soils and urban life throughout human developmental history.

Nonetheless, the polarisation of cities and countryside persists in the separate urban and rural categories of planning policy (see Davoudi and Stead, 2002; Simon and Adam-Bradford, 2016), confirming the societal attitude that urban living is distinct from everyday engagement with soils.

That we conceal our dependency on soils in everyday urban life thus reveals a western cultural bias in urban planning concerns. Since the 1980s archaeologists have been building a body of evidence demonstrating that agricultural practices played an important role in Precolumbian lowland Maya tropical urbanism (e.g., Killion et al., 1989). Over the last decade (Chase et al., 2011; Chase et al., 2016; Canuto et al., 2018) aerial altimetric surface surveys, using LiDAR (Light Detection and Ranging), have afforded archaeologists a view of the full expanse and spatial patterns of lowland Maya urban landscapes. This new line of evidence confirms at rapid pace and large scales the pervasiveness of the integration of urban open space that was previously exclusively documented by assiduous topographical surveys and excavations. Combining frequent evidence of urban horticultural and agricultural practices with these spatial patterns (cf. Isendahl, 2010; 2012) identifies the lowland Maya urban tradition as a particularly promising source of evidence on an approach to urban life in which soil connectivity is foregrounded. 
Maya urban environments have not previously received attention in the context of contemporary soil security. However, within a period of development spanning some 2,500 years, the ancient Maya built their cities according to spatial patterns which deviate drastically from what has become accepted as global paradigms for urban development today. Maya urban landscapes are suggestive of a radically different outlook and expectation of urban life and urban ecological relations, in which soil connectivity was intensive and persistently distributed throughout urban society.

In this paper, we review archaeological evidence that elucidates what is particular about the relationship between Maya urban life and soils. We first assess how the spatial arrangements of vernacular Maya urban design consistently creates opportunities for soil connectivity in urban life by deliberately preserving the availability of, and proximity and accessibility to, unpaved areas of urban open space where soils were used. Next, we consider the material evidence which demonstrates that the urban Maya actively cared for, maintained, and contributed to the formation of soils and soil properties that were beneficial to them. Finally, we consider the range of landscaping and engineering practices the urban Maya employed to preserve and protect soils in their wider urban landscapes.

By reviewing research on these three lines of archaeological evidence we reveal a case of urban soil connectivity with considerable longevity and variety. The insights gleaned on how Maya soil connectivity operated as a practice have the potential to serve as a source of knowledge and inspiration that constitute a new route for stimulating soil connectivity today by increasing engagement with soils. The Maya urban tradition thrived for more than two millennia in challenging environments housing large populations, suggesting that the significance of soil connectivity in urban life played a responsive role by providing soil security in confronting urban 
202 development challenges. We propose that greater engagement with soils will prove 203 pivotal in providing capacity for urban resilience and adaptability. Enhancing soil 204 connectivity can alleviate the sustainable development issues which will arise from 205 the projected global increase in urban populations. 


\section{Environmental Conditions of Precolumbian Lowland Maya Tropical}

\section{Urbanism}

The name 'Maya' loosely describes populations related through culture, history, and language who have occupied the Yucatán Peninsula and adjacent low-lying and highland areas of southern Mexico, Guatemala, Belize, and the western parts of Honduras and El Salvador for more than three millennia (Figure 1) (Sharer and Traxler, 2006). Maya urbanism is notable in that it developed in the absence of grazing animals. Large-bodied mammals such as cattle or sheep were not part of the Maya diet or energy regime (Graham, 1996). Thus, the entire Neotropical (i.e., the tropical areas of the Americas) urban ecology stood in contrast to pre-industrial urban traditions in Eurasia and Africa. Nonetheless, food resources in the Maya world were diverse and abundant. Seed and root crops, tree products, fowl, and smaller-bodied mammals, together with marine, riverine, and lacustrine resources, made up the bulk of the diet (Dunning et al., 2018). The only large-bodied animals were deer, which were hunted but not domesticated (Lundell, 1938; White, 1999;

Emery, 2017), although evidence for careful deer population management has been found at Mayapan (Masson \& Peraza Lope 2008).

The humid tropical environment of the Maya lowlands serves as a kind of laboratory in which generative and decompositional biophysical processes are accelerated.

This acceleration makes these processes more perceptible compared to temperate or semi-arid regions. Where biophysical processes are slower, the built environment tends to outlast the human lifespan. In such climates, there is the common expectation that rubbish, human waste, and bodies of the dead should be separated more or less permanently, from habitable areas. The fate of the material world, which is its disintegration, decay, and subsequent contribution to soil formation, thus 
remains out of sight and out of mind (Graham et al., 2021). Our hypothesis is that in the humid tropical Maya lowlands, acceleration of biophysical processes created greater awareness of decay, its regenerative potential, and its environmental impact (Graham, 1999a). Therefore, the Maya present an interesting case that it would be appropriate for long-term urban planning to account for decay to a greater degree than is currently practiced.

237 Precolumbian lowland Maya tropical urbanism emerged from around 900 BCE. We take the evidence reported on large and complex construction at Ceibal, Guatemala and Aguada Fénix, Mexico (see Inomata et al., 2013, 2020) as early indicators that processes of urbanisation in the Maya lowlands were under way. The construction of monumental architecture is associated with the establishment of major settlement centres showing increasing social complexity. While the exact stage at which these centres can justifiably be described as urban can be debated, between $600-400$ BCE major centres occur across the Maya lowlands that show many characteristics regarded as direct precursors for the settlement principles anchoring Maya urban landscapes thereafter (e.g. Pendergast, 1981; Hansen, 1998; Hansen et al., 2002; Reese-Taylor and Walker, 2002; Braswell, 2012; Pugh and Rice, 2017). Maya urbanism then persists until Colonial town councils are being established from around $1540 \mathrm{CE}$ in the contested process of the Spanish conquest.

Lowland Maya tropical urbanism emerged in a largely karst environment mantled in an array of tropical forest vegetation types (Wagner, 1964; West, 1964). Most of the lowlands are underlain by limestone with karst features such as caves, sinkholes, and solution valleys. Weathering produces little in the way of non-carbonate clastic residuum, although subsoil horizons may contain a large quantity of limestone fragments, chert gravel, and coarse sand. Much of the non-clastic inorganic parent 
material observed in lowland soils is of aeolian derivation, including volcanic ash,

257 Saharan dust, and North American loess (Bautista et al., 2011; Tankersley et al., 2016). While soil cover remains skeletal to thin across more arid regions in the north of the peninsula and on sloping terrain across the entire lowlands, deep, claydominated sediments have accumulated within structural and solution depressions (locally known as bajos), especially in the south (Dunning et al., 1998a; Dunning and Beach, 2010; Dunning et al., 2019).

Rainfall distribution grades from roughly $500 \mathrm{~mm} \mathrm{yr}^{-1}$ on the northwest coast to over $2,500 \mathrm{~mm} \mathrm{yr}^{-1}$ in the far south, but with high inter-annual variability (driven in part by tropical storms/hurricanes) and high seasonality (typically about $90 \%$ falls during the late May-early December wet season). Most rainfall arrives in the form of intense convectional thunderstorms, and rainfall-runoff erosivity indices (R-factors) can be internal. However, in the wet season prolonged rainfall inundates bajos, many of which are interconnected by seasonal surface streams. Additionally, springs discharging at the base of fault scarps along some margins of the interior lowlands feed perennial streams and rivers. Perennial rivers also emerge from adjacent nonkarst regions in parts of the southern lowlands. Perennial wetlands along these systems were often targeted for development of intensive agriculture.

Hence, Maya complex societies developed for well over two millennia within a heterogeneous dynamic environment and soilscape. Population growth, urbanization, and statehood (a step change in settlement scale emerging 1000-600 $\mathrm{BCE}$, starting in the southern (highland) Maya region) co-evolved with the political and social economy. Within and beyond their urban landscapes, the Maya created 
281 unique agricultural systems that by necessity imply strong interconnectedness with 282 soil. In this paper we draw on select examples of lowland Maya urbanism from which 283 we can derive salient insights on the role of urban soil management, many of which 284 date to the Classic (250-950 CE) and Postclassic (950-1540 CE) periods, even 285 though there is evidence for similar principles of soil management in earlier major 286 centres (e.g. Hansen et al. 2002). 


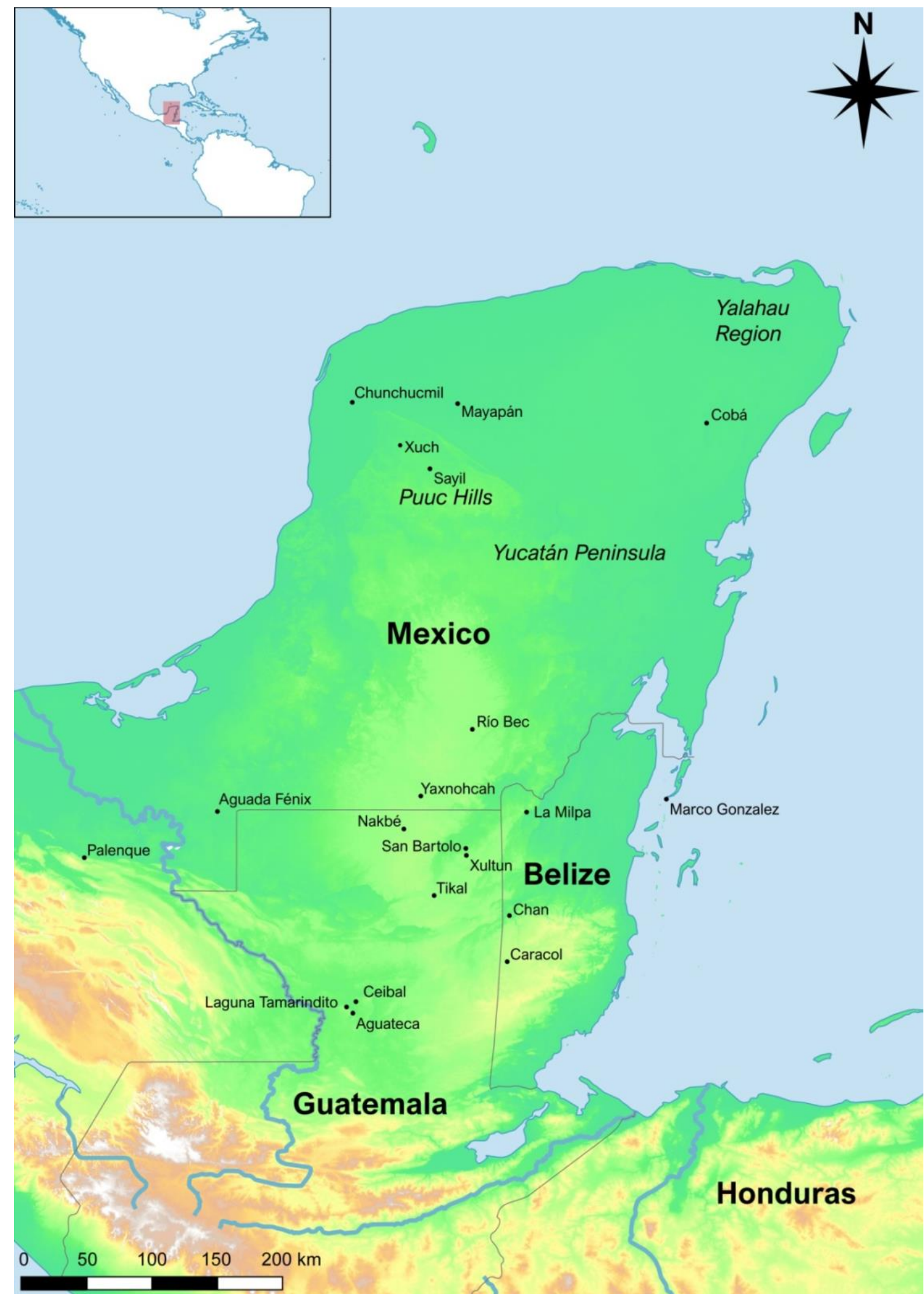

Figure 1: Map contextualising the Maya lowlands situated on the Yucatán

Peninsula, showing the location of the archaeological sites and areas discussed in this paper. 


\section{Space for soils}

In many tropical environments much of urban life and activity takes place outside buildings. Therefore, it is regularly argued that outside spaces must feature as an integral element of any analysis of Maya urban life and organisation (e.g., Smyth et al., 1995; Graham, 1996; Becker, 2001; Robin, 2002; Dunning, 2004; Hutson et al., 2007). The study of Precolumbian lowland Maya tropical urbanism has revealed patterns of dispersed urban landscapes which are characterised by a high retention of urban open space within the intensively developed built environment. In recognition of the relative dispersal of architectural units and population over large expanses of space, researchers have applied different descriptive labels. These labels capture the idea that the form of lowland Maya tropical urbanism differs from models of urbanism prevalent in ancient Europe and contemporary globalised society: tropical urbanism (Graham, 1996), garden cities (Tourtellot et al., 1988; Chase and Chase, 1998), green cities (Graham, 1999b), agrarian cities (Arnauld, 2008), low-density urbanism (Fletcher, 2009), and agro-urban landscapes (Isendahl, 2012; Graham and Isendahl, 2018). To understand the particularities of major urban centres of lowland Maya society, it is necessary to include the direct hinterlands, or what is currently approached as peri-urban settlement (e.g., Simon and AdamBradford, 2016). In this paper we apply the Maya agro-urban landscape label to reflect that hinterlands and peri-urban settlements should be seen as fully integrated in how the city functioned, instead of viewing social practice as polarising the urban centre to the rural hinterland (see Figure 2a; Graham, 1999a; Hirth, 2003; Dunning, 2004; Isendahl, 2012; Graham et al., 2017; Graham and Isendahl, 2018; Dunning et al., 2019). 


\subsection{Integrated open space in Maya urban environments}

313 Within the relative abundance of space in Maya tropical urban environments, it is

314 crucial to our arguments to appreciate the proportion of urban space that would have been built-up or paved over. The civic-ceremonial cores of Maya cities were characterised by large-scale monumental construction comprising multiple architectural complexes in which buildings on terraced platforms were arranged around open spaces. The smaller open spaces are normally associated with residential groups and are called patios; the larger plazas are associated with civic, administrative, and ceremonial complexes. In a number of lowland Maya cities, consistencies in the architectural layout of building groups sat on or around paved plazas have been identified as recurrent plan types (e.g. Becker, 1982; 2001; Magnoni et al., 2012; Magnoni et al., 2014). In terms of infrastructure, Maya urban environments could feature integrated agricultural infields, large water management systems, and defensive works, but frequently they lacked an apparent formally constructed street network. Nonetheless, many Maya urban environments featured a number of paved, wide formal causeways (sacbeob) that link up particular architectural groups or entire city centres, or connect outlier centres (Shaw, 2001, 2008; Canuto et al., 2018). Architectural groups, whether residential, public, or administrative, are typically arranged facing inwards around an open space. Often the buildings are constructed on top of a shared raised platform, which would provide a paved area that connects the architectural configuration (e.g. Ashmore, 1981; see Figure 2b). Platforms could have pronounced steps on all sides or have a side which slopes down, but there is considerable variety in shape and construction depending on the 'region' and topography in which they occur. Following the emphasis on agrarian aspects of Maya livelihoods, architectural groups outside the civic- 
ceremonial core are inferred from archaeological evidence to have been residential units functioning as urban farmsteads. They comprise multiple buildings for an agrarian-based extended family, such as kitchens, living quarters, latrines, storage

340 units, etc. (Becker, 2001; Dunning, 2004).

341 The pattern emerging from the arrangement of distinct urban open spaces in-

342 between and connecting built form in the Maya lowlands has been usefully

343 generalised in an abstract visualisation, see Figure 2a (cf. Barthel and Isendahl, 344 2013, p. 226; Isendahl, 2012). Since we would expect to find urban soils in unbuilt open space, the large expanse of seemingly 'empty' white space in combination with

346 the grey 'productive' space in Figure 2a is especially interesting here. Their presence

347 and relative location suggests that the availability of, proximity, and access to 348 unpaved open space in the Maya urban environment was carefully managed and 349 preserved as cities were developed. 

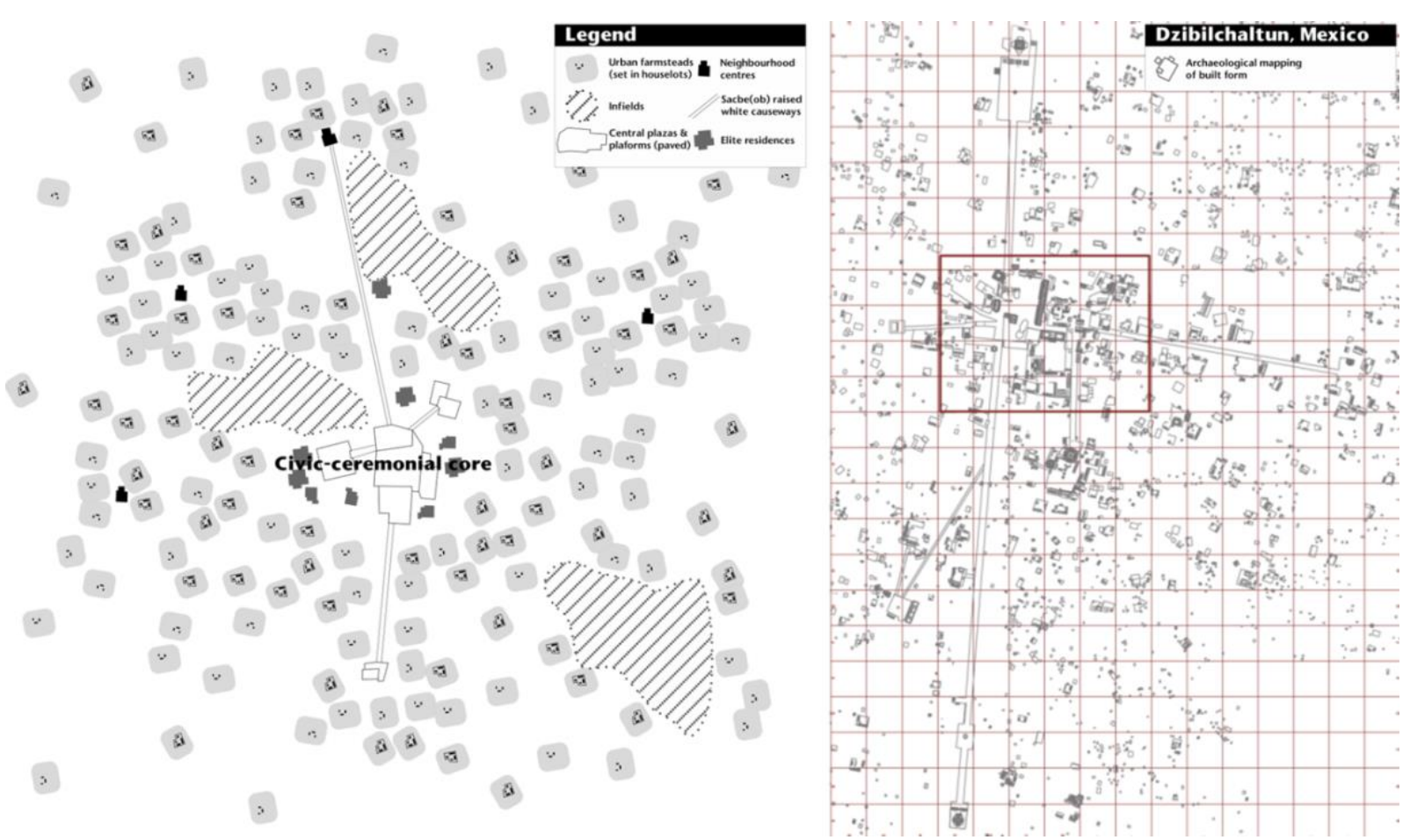

Figure 2: (a) Idealised abstraction of the general spatial plan of lowland Maya tropical urban settlements (a redesigned enhancement by Benjamin Vis of that contained within Barthel and Isendahl, 2013). (b) This archaeological map resulting from a topographical survey of Dzibilchaltun, Mexico provides an example of the spatial settlement and architectural patterns of a lowland Maya city situated on flat topography (Peiró Vitoria, 2015; redrawn from Stuart et al., 1979). 
352 Examples of Maya urban environments with relatively good preservation and visibility to carry out detailed topographical mapping have revealed densely developed urban patterns in which the seemingly loose arrangement of built environment features gives greater morphological definition to the abundance of urban open space. Such increased clarity in the patterns of urban form especially applies to the houselots in which Maya farmsteads are placed, which for example are clearly bounded by dry stone walling (albarradas) at the cities of Chunchucmil, Mexico (Figure 3a) and Mayapán, Mexico (Figure 3b) (Vis, 2018). Houselots are known from ethnographic research in the Maya lowlands, including contemporary use of pole fencing marking garden boundaries at Cobá (Fletcher \& Kintz 1983; Kintz 1990). In the village of Joya de Cerén, El Salvador, the multipurpose garden areas in which polyculture was practiced were so composed that household association was clearly delineated without the need for material demarcation (Slotten et al. 2020). Becker (2001) proposes spatial models for the division of houselots: completely contiguous landuse cover (Model A); a commons type (Model B) where socially exclusionary houselot divisions leave ample shared or public space in-between; and an open type (Model C) of intermediate land-use cover, leaving pathway connections and some additional in-between space. These models cover a range of possible configurations that could explain different spatial associations with landscape features. In each model the surface area of urban open space remains the same. What differs is the scale of control and social organization over urban land-use. In settings with significant relief, such as at Palenque, Mexico, steep topography concentrated the planned infrastructure, residences and civic-ceremonial core in levelled valley areas and pushed cultivation out onto channelized fields in surrounding wetlands and terraces on nearby gentle slopes (Barnhart, 2001; 2005; Liendo Stuardo, 2002). 


\subsection{Urban space designed to keep soils close}

Maya urban built environments display a typifying looseness that reflects the principle of integrating the productive open space usually found in peri-urban settlement and direct hinterlands. Detailed topographic mapping of architectural and landscaping features indicates that the perceived looseness resulting from pervasive open space should not be mistaken for emptiness. The representation of lowland Maya tropical urban environments in Figure 2a can therefore be deceptive. Increasingly, evidence on Maya urban environments suggests that many spaces were bounded and dedicated to intensive productive activities, including diverse agricultural specialization. It is also recognised that some perceived topographical emptiness could result from archaeologically 'invisible' settlement, due to the extensive use of perishable building materials (e.g., Johnston, 2004; Hutson and Magnoni, 2017). Maya urban open space should therefore be regarded in terms of gradation of openness, also comprising degrees of construction serving a variety of household and other functions including walling, screens, and fencing, functional coverings, wooden buildings (see Graham, 1996). Site-wide phosphate sampling covering the dispersed settlement pattern at Sayil, Mexico, demonstrates that most of the flat open terrain would have been used for intensive gardening and agricultural practices (Smyth et al., 1995). Likewise, the settlement pattern of Chunchucmil permits soil retention within houselots themselves (cf. Fletcher, 1983; Sabloff, 2007 also mentions potential benefits to moisture retention). While Chunchucmil's soils are known to be thin and of poor quality, Dahlin et al. (2005, p.239) note that "phosphorus replacement is the most limiting factor" to their fertility, and provide 
evidence for soil enrichment and possible raised beds within the urban farmstead arrangement (see also Hutson et al., 2007).

In the Río Bec region, southern Yucatán Peninsula, Mexico, Lemonnier and Vannière (2013, following Eaton, 1975; Drennan, 1988) argue that the spatial distribution of households or farmsteads over large expanses of space results from an intensive infield-type agricultural practice around the houses (cf. Figure 2a). There is ample evidence that the spaces between building groups at Río Bec have been transformed through careful land management with many types of microtopographic modifications (Lemonnier and Vannière, 2013). Soils proximate to dwellings on higher interfluves "were modified, managed and some of them even improved [by domestic waste spreading] [...] and, at a lower level, the slopes were terraced to preserve soils from erosion" (Lemonnier and Vannière, 2013, p. 404; Figure 3c). Linear stone ridges divide the landscape and are interpreted as barriers used to demarcate space as well as to control the drainage of rainwater (Lemonnier and Vannière, 2013). This dual use recalls the function and patterning of houselots by dry stone walls elsewhere, for instance at Chunchucmil, Mayapán, and Cobá, Mexico.

In relatively densely occupied Chunchucmil, dry stone walling comprehensively bounds houselots throughout most of the city, allowing recognisable pathways for circulation to emerge (e.g., Magnoni et al., 2012; Figure 3b, cf. Becker's (2001) Model C). At Río Bec, the distribution of archaeological remains helps to distinguish residential zones from several distinct areas of intense cultivation with managed soils suggesting complementary specialised agricultural uses, whereas the absence of archaeological material may indicate circulation spaces (Lemonnier and Vannière, 2013). The crucial suggestion of the layout in the cases of Chunchucmil and Río Bec 
is that the task-orientation of household units (cf. Wilk and Ashmore, 1988) translates into a priority to preserve their envelopment in distinct houselots offering significant amounts of open space. The virtue of carving up space into household units within which built volumes would be grouped is that such subdivision of open space and configuration of buildings determine frequent access points and encounters with soils throughout the urban landscape on a daily basis.

The nature of settlement organisation in the Río Bec region has drawn into question whether the notion of urbanism is applicable here, especially due to the lack of clustering around major epicentres (e.g., civic-ceremonial cores, see Figure 2a and 2b) which characterises many other lowland Maya urban environments (Nondédéo et al., 2013). Yet, it is worth noting that the density of structures recorded at Río Bec overall still concurs with the range of dispersed agro-urban landscapes found elsewhere in the Maya lowlands. In terms of the size of the area of each agricultural production unit the difference is more significant, with areas bounded by ridges and berms averaging ca. 13,000 $\mathrm{m}^{2}$ (Lemonnier and Vannière, 2013). This stands in contrast to the undisputed urban settlements of Cobá $\left(1,795 \mathrm{~m}^{2}\right.$ excluding architecture), Chunchucmil (3,595 $\mathrm{m}^{2}$ excluding architecture, based on a $36 \%$ sample), and Mayapán (845 $\mathrm{m}^{2}$, including architecture, based on a small 2.7\% sample) (Magnoni et al., 2012). Lemonnier and Vannière (2013) proffer that dry stone walling in northern Yucatán is perhaps associated with smaller scale household gardens, whereas the Río Bec field systems are formed by more elaborate ridges. One might further speculate that part of the discrepancy between Cobá and Chunchucmil could be due to the difference in the local stock of soils and soil properties between these cities and consequential specialist productive activities. It should also be acknowledged that the areal extent of the topographical 
450 mapping efforts at Chunchucmil have been more comprehensive than the sampled

451 mapping carried out at Cobá prior to the recent capture of LiDAR (Miller et al., 2018).

452 Meanwhile, Mayapán's dense settlement pattern, with a large central core bounded

453 by a defensive wall, reflects the essential socio-political transformations of a few

454 centuries later. 


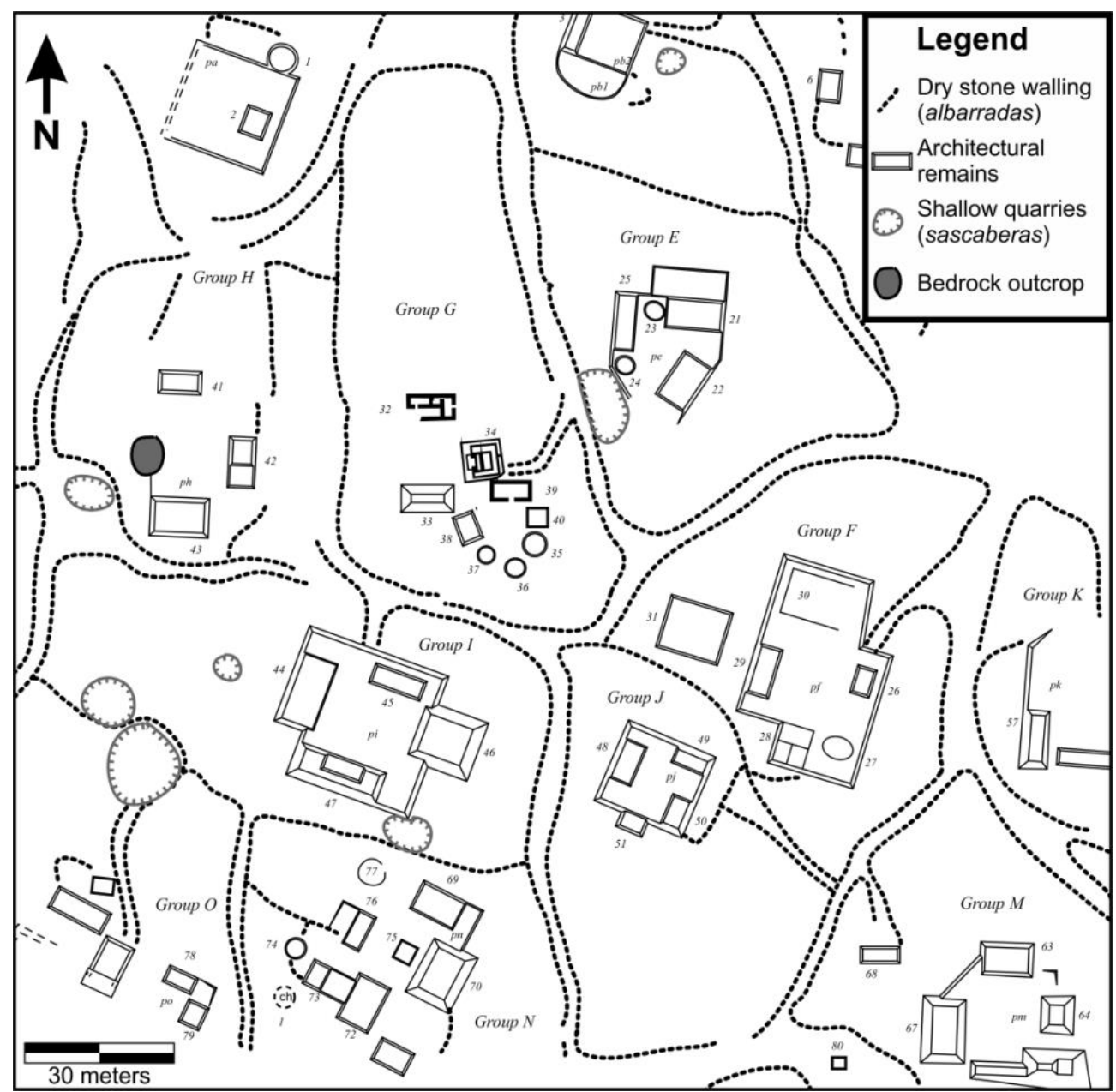

b

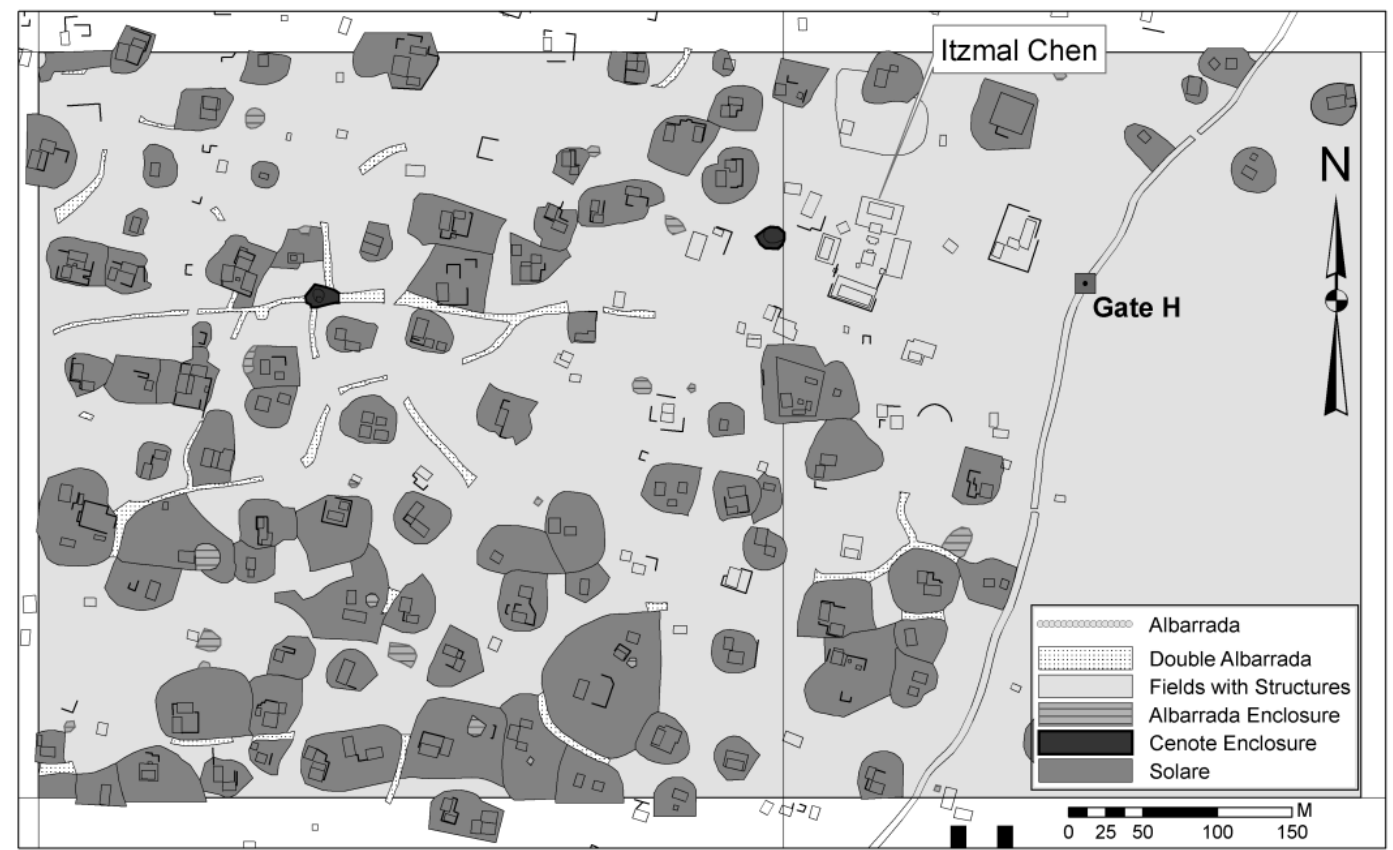


C

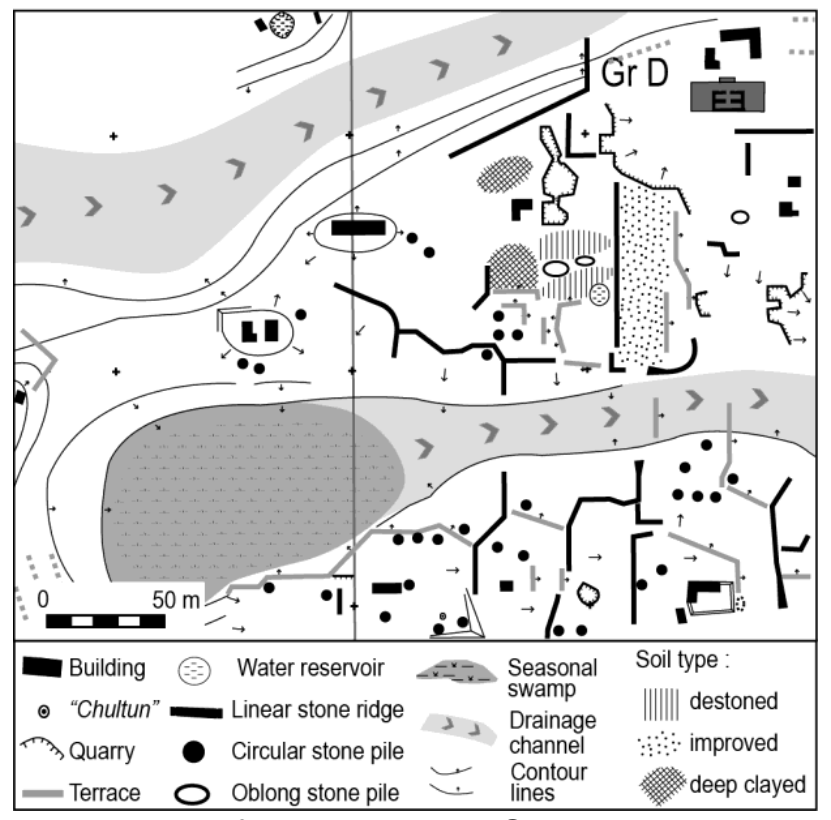

Figure 3 (a) Households or urban farmsteads at Chunchucmil, Mexico, situated in houselots bounded by dry stone walls (albarradas) (reproduced from Magnoni et al., 2012, p. 317, courtesy of Pakbeh Regional Economy Project)

Figure 3 (b) Households or urban farmsteads at Mayapán, Mexico, situated in houselots bounded by dry stone walls (albarradas) (reproduced from Hare et al. 2014 , p. 165 , courtesy of T.S. Hare)

Figure 3 (c) A sample area of interpretation of landscape modification and soil management in the Río Bec, Mexico, nuclear zone (reproduced from Lemonnier and Vannière, 2013, p. 404, courtesy of E. Lemonnier and B. Vannière) 
456 From these examples of the relationships between dwellings and outside space it is

457 clear that encounters with soil would be commonplace in Maya urban life. Taking residential buildings as a point of departure, soils would be visible, available, accessible, and interacted with on a daily basis (see Vis et al., 2020 for examples of what this could look like for urban design challenges today). Besides evidence of architectural and landscaping features, the detailed studies of the spatial distribution of phosphate concentrations can further specify different zones of land-use on the basis of human interaction with soils in the urban environment, as exemplified by Sayil in Figure 4 (Dunning, 1992). Phosphate concentrations within the platform group itself are most likely indicative of food preparation. The south-eastern distributed zone of phosphate concentration suggests the net deposition of organic material for fertilisation, such as human waste, food waste, and mulch. The clear zonation in the detection of phosphate concentrations implies that not all of the houselot was used equally, and that, in some areas, deliberate effort was made to fertilise the soil. Similar practices have been interpreted on the basis of phosphate analysis at Xuch, Mexico (Isendahl, 2002).

Since evidence of Maya toilet or latrine practices or infrastructure is virtually absent, it stands to reason that houselot gardens would have had a toilet area and a cesspool (cf. Becker, 2001). Households by and large would have had space available to compost their organic and human waste themselves. Aided by fast tropical decomposition and cycling, after processing, composted waste would have been distributed where desired (cf. Dahlin et al., 2005). Becker (2015) suggests night soil may have been a traded commodity. Onward trading of night soil has been particularly documented in Imperial China and Early Modern Japan. Prior to industrialisation and hydraulic flooding the collection and removal of night soil from 
urban residents, often for subsequent distribution on agricultural fields, was a common practice to maintain soils' capability of food production by nitrogen and phosphorus fertilisation (Kawa et al., 2019; see also Isendahl and Barthel, 2018 for contemporary practices of collective urban action for human waste circulation).

Dahlin et al. (2005) are beyond doubt that household and human waste was collected, processed, and spread on gardens at Chunchucmil, but indicate it may have been too little to sufficiently improve the soil's phosphorus and nitrogen content. They argue instead for additional strategies of soil enrichment, such as importation of organically rich soils, mulching, and possibly introducing periphyton (see 4.2, also Beach, 2016).

Given the dependence of the population on labour-intensive garden agriculture at both Sayil and Chunchucmil, and the indication of a level of elite coordination or control by the co-occurrence of elite residences with the best soils at Sayil (Smyth et al., 1995; Dahlin et al., 2005), it is plausible that commodities associated with soil maintenance were highly valued and would have been traded. We note that periand ex-urban agricultural outfields at Sayil and Aguateca, Guatemala show significantly depleted phosphate levels (Smyth et al., 1995; Dunning et al., 1997; see also Isendahl, 2012). This observation lends credence to the advantage of access to fertilisation resources, such as importations of soil organic matter, household waste, and human waste, within the urban settlement and in everyday urban practice. 


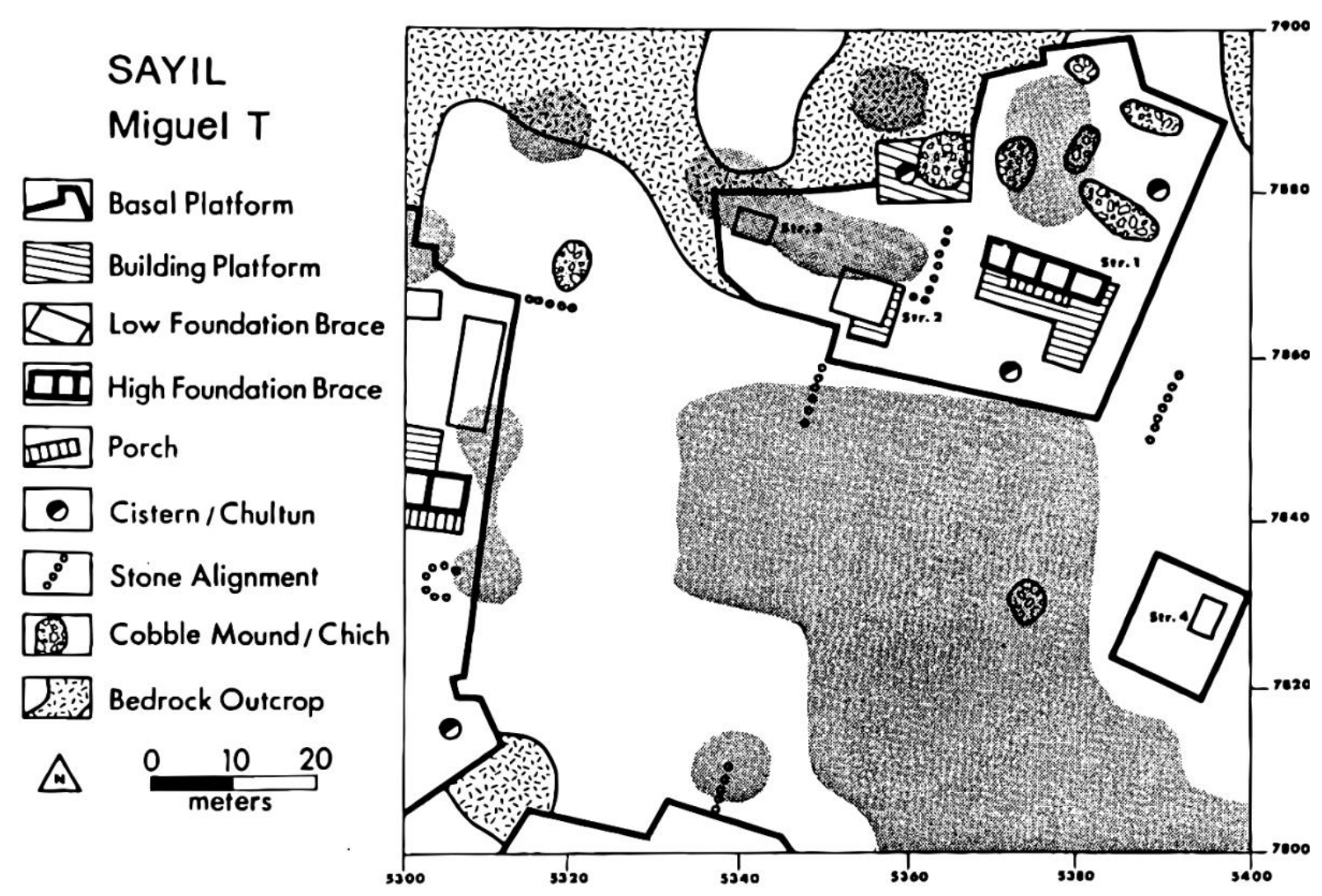

Figure 4: Distribution of phosphate concentrations (the darker shaded areas)

suggesting different land-use zones at the Miguel T houselot at Sayil, Mexico (image reproduced from Dunning, 1992, following Killion et al. (1989)

Even if the impact of soil fertilisation of any category would have been limited, the daily household practice of collecting, processing, and depositing waste would have greatly promoted an urban life stance with high soil connectivity. The multivariate landscape modifications occupying topographical relief evidenced in many cities and the intricate and intense patterns of land-use divisions in Maya agro-urban landscapes suggest a conscious effort to safeguard areas in which to maintain, accrue, preserve, and enhance soil properties that are beneficial to urban life. These landscaping and urban design strategies would have been associated with the careful management of material resources and (organic) waste. Since the 
512 multipurpose houselots that surround residential groups ensure continuous

513 encounters with soils, the benefits of soil management would have become an

514 inevitable structural task of everyday urban life. When household gardening was at

515 least relied upon to provide partial subsistence in most lowland Maya tropical cities,

516 this would have involved proactive interaction with soils to maintain their capability.

517 To sustain the day-to-day functioning of urban life, crucially, the characteristic

518 patterns of sub-divided urban open space in lowland Maya urban design generated a

519 condition of spatial contiguity in which the occurrence of soil connectivity is

520 constantly promoted. 


\section{Contributing to soils}

522 Today, a spirit of dependence on local soils by local communities has been replaced

523 by international trade and global transport networks (Barthel et al., 2019). Reliance

524 on global food trade and the simultaneous dispensability of self-sufficiency contribute

525 to the disconnect, or metabolic rift, that has manifested between local communities

526 and their soils. The Precolumbian Maya preceded the emergence of global food

527 markets and supply chains. With no beasts of burden and many inland regions

528 lacking navigable rivers, food transport was often restricted to human transport over

529 land and challenged by the difficulty of preserving foodstuffs in the tropical climate

530 when travelling large distances. This procurement situation would have stimulated at

531 least a degree of reliance upon maintaining the food system cycle using local soils to

532 grow food and process waste.

533 Given the solubility of the calcareous bedrock that dominates the area, residual soils

534 would have been shallow (often $<0.5 \mathrm{~m}$ deep). Moreover, the shallow nature of the

535 upland soils would have curtailed their capacity to support a number of cultivation

536 practices, such as the production of deep-rooting crops (Dunning et al., 2018).

537 Geoarchaeological explorations of lowland sites have documented soils that present

538 a clear contrast to those that would be expected for regions underlain by a

539 limestone-dominant lithology. In response to the shallow nature of the residual soils

540 in urban environments, the Maya engaged in facilitating and enhancing soil

541 formation. Proactive contribution to soil formation processes would require a more

542 intensive engagement with the soil resource than is typically observed today

543 (Dunning and Beach, 2003). Soil studies of Maya urban centres have revealed complex soil histories replete with episodes of both destructive and constructive soil 
management practices (Beach et al., 2006; Beach et al., 2018; Dunning and Beach, 2000; 2010; Dunning et al., 2019).

\subsection{Unintentional soil enhancement}

There is much debate in the literature as to whether the formation of soil and enhancement of soil health observed in the humid tropics was an unintentional effect of a series of human behaviours or deliberate soil management (Arroyo-Kalin, 2019). Unintentional soil enhancement could result from people discarding waste, abandoning buildings and household lots, and burying the dead (Graham, 1998, 2006). In addition, fast decomposition in the tropics causes decay through which material for soil enhancement can accumulate. We suggest here that Maya urban farmers discovered, likely through trial and error in practice, that maintaining and increasing the local stock of soils, in particular enhancing their thickness and soil organic matter, contributed to long-term soil health and sustained agricultural productivity. The tropical decomposition cycle could have resulted in an elevated awareness of the material decay of structures, artefacts, and discard in Maya cities, leading to an additional opportunity to contribute to local soil formation. In other words, opportunistic practices that seemed to promote the health and functioning of soils could have developed over time into more intentional actions (Graham, 1998; Graham et al., 2021).

The presence of 'dark earths' (Arroyo-Kalin, 2014a) in Amazonia (Arroyo-Kalin, 2014b; Glaser and Woods, 2004) and in the Maya area (Graham et al., 2017; Macphail et al., 2017) warrants our attention in the context of unintentional soil enhancement. They reflect an association between fertile soils and tropical human 
settlement that has been intensively studied, most notably in Amazonia. In summarising the research on Amazonian Dark Earths (ADEs), Arroyo-Kalin (2014b) makes clear that a variety of contexts must be considered for its formation. In the Amazon, different kinds of dark earth are associated with a variety of land uses, with particularly deep and fertile ADEs formed by a build-up of midden or refuse material associated with sedentary settlement and less organically-rich ADEs with less intensive and repetitive behaviour, including past slash-and-char agricultural practices (Lehmann et al., 2003; Steiner et al., 2004; Glaser and Birk, 2012; Nigh and Diemont, 2013; Niu et al., 2015).

The first Maya Dark Earths (MDEs) identified occur at the site of Marco Gonzalez, on the southern tip of the Ambergris island or caye off the coast of Belize (Graham et al., 2017; Macphail et al., 2017), although it should be noted that dark earths characterise most, if not all, archaeological sites on the caye (see map in Guderjan, 1995). Occupation dates from about 300 BCE to the $16^{\text {th }}$ century CE, with limited occupation continuing through to the present day. In accordance with many Amazonian cases, at Marco Gonzalez, refuse middens and a variety of settlement construction and occupation activities, including the burning of wood fuel in saltmaking activities and extensive human burial, are implicated in the accumulation of soils and sediments, and ultimately in the formation of dark earth (Macphail et al., 2017).

The physical, chemical, and biological constituents of MDEs contradict what one would expect to observe from natural pedogenesis over coral and Pleistocene limestone that comprise the parent materials of the Belize Barrier Reef (Gischler and Hudson, 2004). The full soil and sediment profile that has been exposed above sea level is over $2 \mathrm{~m}$ in depth, with an organic and alkaline surface soil horizon, 
bioturbated with humic mineral and litter material. Soil micromorphology has shown that this surface soil horizon is dominated by bone, ash, and very fine charcoal-rich deposits. Underlying the surface horizon are layered deposits of relatively intact ash and charcoal layers, together with bone-rich kitchen midden waste. Deeper horizons show similar interbedded sequences of burned bone, ash, and charcoal, and evidence for both human and faunal remains (Graham et al., 2017; Macphail et al., 2017). Given the spatial coverage of the anthropic horizons, indications are very strong that activities of the Precolumbian Maya contributed significantly to the formation and depth of these soils.

Unlike some of the Amazonian cases (Arroyo-Kalin 2014b) and post-colonial examples in the tropical forests of Guatemala (Nigh and Diemont, 2013), in the inherently nutrient-poor soil that naturally formed at Marco Gonzalez, burning associated with cultivation is not likely to have contributed to the formation of MDEs. It is possible that when the bulk of Marco Gonzalez's occupants moved northward, ca. $1200 \mathrm{CE}$, as the encroaching mangrove vegetation limited access to open water (Dunn and Mazzullo, 1993), enough dark earth began forming to permit some cultivation (Graham, 1998). Accepting the supposition that the Marco Gonzalez MDEs became cultivable sometime later during the Postclassic (ca. 1200-1400 CE), preparatory burning of vegetation may well have taken place, and indeed continues to modern times. Intensive construction in the context of tourism has obliterated many dark earth sites, but where they exist, and where burning is not practical, the soils are transported to people's household gardens.

The MDEs identified at Marco Gonzalez may have accrued unintentionally. Notwithstanding the desirable qualities of such dark earths, the thin, limestone residuum prevalent across the Maya lowlands would have been insufficient to 
sustain urban life without active contribution towards its thickening. Simply fertilising these residual soils would have been inadequate to facilitate their cultivation. The seminal role of the urban Maya in the lowlands, if not evidentially deliberate, was specifically the thickening of the soil profile which improved productivity. As urban residents became aware of these benefits, the activities towards forming soils promoted soil connectivity. Even though the Classic Maya at Marco Gonzalez may not have enjoyed the benefits of the dark earths emerging from their urban practices, it is worth appreciating the principles by which these soil qualities could develop. Crucially, Maya urbanism shows that inadvertent effects of urban occupation can be one aspect of soil connectivity for improving urban soils.

\subsection{Deliberate soil enhancement}

The multifarious benefits of how Maya urban practices unintentionally improved the productivity of the soil will have been recognised and capitalised upon. First, such soil management was essential in sustaining socially intense urban life on the residual soils in the lowlands. Next, the knowledge gained through increasing the use-value of soils will have structured their behaviours purposively, including deliberate and planned soil management techniques. These practices integrated soils into everyday urban life, inevitably enriching soil connectivity.

As we learned from the studies of urban design and the zonation of activities revealed by phosphorus analysis in Sayil and Chunchucmil, and further corroborated by cases such as Xuch and Aguateca, the practices of Maya urban life will have included regimes of soil fertilisation utilising organic and human waste from residents. Soil formation was also intentionally enhanced by the labour-intensive 
practice of importing organic wetland soils from areas outside the immediate urban built environment (see also 3.2). In the Yalahau region, northern Quintana Roo, Mexico, the mining of organic wetland soil to amend garden beds has been documented through the identification of residual periphyton in soils in ancient walled gardens far from their wetland source (Fedick and Morrison, 2004). While the evidence from the Yalahau region has come from sampling of smaller scale settlements, we have evidence for similar practices at the large city of Chunchucmil on the arid northwestern coastal plain. Here, importation of organic matter from adjacent wetland savannas likely made a significant improvement to urban soil condition (Beach, 1998; 2016; Dahlin et al., 2005).

The mapping of soil phosphate levels both within and outside of lowland Maya urban centers (cf. Figure 4) provides the evidence to support the extent of these practices. Phosphorus is the essential soil nutrient in shortest supply in much of the Maya lowlands, and it is well known that over time human activity greatly affects the distribution of phosphorus within the soil-scape (Holliday and Gartner, 2007). The majority of lowland Maya urban centers where soil phosphorus has been studied show a net enrichment within known or suspected garden and infield areas, which suggests sustained organic enrichment (Isendahl, 2002). As mentioned, human waste was certainly one source of organic enrichment, but wetland mucks (where available), green mulches, and organic waste are also likely sources. In contrast, many outlying or rural fields that have been studied show net soil phosphate depletion, indicative of lacking such sustained enrichment. This phosphate depletion is probably — at least in part — attributable to the unavailability of sufficient 'fertilizer' 666 (Dunning et al., 1997). While we lack direct evidence for composting practices, there 667 is some evidence that the Maya segregated organic and inorganic wastes in their 
middening (trash disposal) practices (Eberl et al., 2012). Waste separation would have facilitated composting and tropical decomposition cycles would have made composting a relatively quick and effective process.

Results from detailed archaeological excavations at houselots in Chunchucmil indicate that soil properties would have allowed less than $10 \%$ of houselots to be used as cultivable gardens (Hutson et al., 2004; 2007). While currently little soil erosion occurs, Beach et al. (2017) report there is clear evidence of previous soil erosion, hypothesised to have occurred during Precolumbian occupation. The evidence suggests that soils might have been thicker in the period of Maya occupation and additional research uncovered greater soil depth in cavities and modern quarries used to deposit soil. The thin soils swept off surfaces in order to construct patios and high use traffic areas were possibly being deliberately placed in gardens (Beach et al., 2017). In northern Yucatán, practices of soil deposition and preservation are known. Karst sinkholes (rejolladas) and depressions would have accumulated rich and moist soil, while frequent gravel piles (chich) may indicate arboricultural use as stone mulch to preserve moisture in shallow soils (cf. Kepecs and Boucher, 1996; Isendahl, 2002; Lemonnier and Vannière, 2013; Hutson and Magnoni, 2017). Owing to the low natural fertility of soils in the northwest coastal plain, agricultural self-sufficiency would have been challenging at Chunchucmil. Yet, thanks to a range of fertilisation and intensification practices, Dahlin et al. (2005) have not been able to completely rule it out either. Houselot soils would have required large input of plant-essential nutrients and soil organic matter to ensure the soils' capability for cultivation, which a combination of rich soil importation, soil deposition, organic waste processing, and mulching could effectuate. Pot agriculture and extensive raised beds, still known in the area as k'anche (Caballero, 1992; 
693 Hutson et al., 2007), would have further expanded cultivation opportunities and 694 productivity (Dahlin et al., 2005; Hutson et al., 2007; Beach et al., 2017). Due to the reliance on perishable materials, soil erosion, post-deposition processes, and rapid 696 tropical decomposition rates, direct evidence of many of these practices is lacking. 697 Nonetheless, there is evidence of the successful cultivation of fruit trees (Hutson et 698 al., 2004; 2007).

699 The fact that urban agricultural practices could have met a significant proportion of 700 the nutritional needs of populations in major urban centres is persuasive. The added 701 value of soil enhancement practices is especially apparent in areas with particularly thin soils, such as Chunchucmil. The evidence that the urban Maya made conscious efforts to increase the local stock of soils, to enhance soils' availability, proximity, and accessibility, and to manage soil health in the city is by no means limited to areas of particularly thin soils. Several settlement centres across the Maya lowlands provide lines of evidence that reveal a range of urban practices resulting in soil enhancement, even if not all enhancements may have been intentional. Both intentional and unintentional soil formation and enrichment practices we have identified from the archaeological record could inform strategies to improve soil connectivity in such a way that it directly strives to provide soil security on an urban 711 level. 


\section{Caring for soils}

714 At this point we understand both the necessity for urban soil formation and the partial

715 reliance on local urban food production. Both would have stimulated Maya appreciation of soil connectivity. We have explored evidence indicating at least two distinct socio-cultural practices in Precolumbian Maya cities that promote productive soil-society relationships. First, developing urban design that secures the availability of urban open space as infields and horticultural plots for extended family households will have increased both proximity and accessibility to soils in urban areas. Maya urban design so promotes opportunities for soil connectivity in urban life. Second, effective soil connectivity is manifest in the deliberate, and sometimes unintentional, formation of cultivable soil resources, using organic waste products, mulches, and other forms of enrichment. A third, and final, aspect of soil connectivity to be reviewed here is that of an increasing consciousness of soil degradation, and the need for intervention.

Evidence for soil erosion in the Maya lowlands is widespread, especially in the southern lowlands (e.g., Beach et al., 2006, 2008, 2015; Dunning and Beach, 2000). Some early models, based mainly on poorly constrained dating of lake sediments, argued that soil erosion rates accelerated steadily through time, peaking with human population in the Late Classic period (ca. 600-800 CE) (e.g., Rice, 1993). More recent studies of lacustrine sediments, including from smaller lakes and ponds, along with seasonal or perennial wetlands within karst depressions, has produced more nuanced understandings of soil erosion. In many instances, soil erosion was most severe in the Preclassic (ca. 800 BCE-250 CE) and tapered in the Classic (ca. 250$800 \mathrm{CE})$, though to what extent this change was due to the implementation of conservation measures or there being simply less soil remaining on slopes to be 
eroded is not always clear (Anselmetti et al., 2007; Douglas et al., 2015; Beach et

al., 2018; Dunning et al., 2019). In some cases, pulses of erosion are evident, including peaks in both the Late Preclassic (400 BCE-100 CE) and again in the Late Classic (600-800 CE) (following Sharer and Traxler, 2006). For example, at Laguna

Tamarindito, Guatemala, pulses in sediment deposition can be linked first to shortening fallow periods in the Preclassic (Dunning and Beach, 2010), then to the implementation of conservation techniques in the Classic (Dunning et al., 1998b). At

Yaxnohcah, Mexico, quarrying and construction of monumental architecture destabilized sloping land above a large adjacent bajo on multiple occasions. The resulting deposition pulses were later arrested by the construction of footslope terraces (Dunning et al., 2019). In Maya landscape history episodes of early landscape degradation may have been followed by later conservation intervention, which then would seem to reflect a soil conservation consciousness that grew over time (Dunning and Beach, 2003; Dunning et al., 2009).

The most obvious evidence for ancient soil conservation in the Maya lowlands is seen in relict terrace systems, for instance at Caracol, Belize (Chase and Chase, 1998; Chase et al., 2011). Maya agricultural terraces are notoriously difficult to date because artefacts are typically scarce and highly weathered, and ancient carbon is rarely recovered. Nevertheless, as more terraces are excavated, our understanding of their historical development increases. Clearly, terracing was being used in at least a few sites in the southern lowlands beginning early in the Late Preclassic (ca. 300 BCE), such as at Nakbé, Guatemala (Hansen et al., 2002) and San Bartolo,

760 Guatemala (Garrison and Dunning, 2009), and was probably more widespread. However, the large majority of known terrace systems date to the Classic period. 
Although there are numerous ways to classify terrace types, four basic types are commonly recognized in terms of landscape position and form: contour, footslope, cross-channel, and box (Beach and Dunning, 1995). Contour terraces are by far the most common. As the name implies, these terraces are single walls, or sets of linked walls, that are fit to mid-slopes and slope crests essentially following lines of elevation. Footslope terraces are found at the base of slopes, often very steep slopes lacking contour terraces (Figure 5). The wall at the base of the slope was designed to salvage whatever soil might move downslope. Cross-channel terraces, often referred to as check dams, were positioned within small seasonal stream courses to trap sediment and build planting surfaces. Box terraces were typically built on low slopes, with walls essentially enclosing a section of terrain, perhaps as support for raised soil beds (Figure 6). The stone walls used to construct terraces also exhibit a great deal of variability. At their most informal, such walls formed a 'broad-based berm' with a core of larger stones anchoring a broad heap of smaller rubble (Beach and Dunning, 1995). In other places more formal construction employed either a single front retaining wall usually backed by rubble, or two vertical walls with rubble fill between them (e.g., Lemonnier and Vannière, 2013).

The use of terracing exhibits tremendous spatial variation across the Maya lowlands (e.g. Canuto et al., 2018). The elevated interior of the lowlands includes large areas of hilly terrain and many examples of areas in which Precolumbian populations invested considerable energy in constructing terraces as landesque capital (e.g., the large center of Xultun, Guatemala as described by Garrison and Dunning (2009)). However, some places, including sizeable urban centers, exhibit very little stone terracing. In the southern lowlands, only a few stone terraces have been found at the great Maya city of Tikal, Guatemala, only $30 \mathrm{~km}$ to the southwest of Xultun, despite 
extensive mapping and LiDAR survey (Dunning et al., 2015). At the northern end of the elevated interior region, there is almost no agricultural terracing associated with dense settlement in the Puuc Hills region in Mexico (Isendahl et al., 2014; see below).

Among the most extensive areas in which widespread agricultural terracing has been documented is the Río Bec region discussed in section 3.2, Lemonnier and Vannière (2013) argue that terracing and land-use divisions, which are fully integrated into the settlement at Río Bec's nuclear zone, arose as an adaptive response to the challenges of cultivation on hilly terrain independent of state-directed initiatives. In short, topography alone cannot explain the distribution of terracing.

In some instances, excavations of terraces and associated soil studies have revealed that erected terraces functioned to trap and accumulate soil mobilized on slopes. That is, the soil bed behind the terrace wall was created by colluviation, or alluviation in the case of cross channel constructions (e.g., Beach et al., 2002). In other instances, the Maya apparently mined soil from other locations and manually deposited it behind terrace walls, including examples from Nakbé (Hansen et al., 2002) and La Milpa, Belize (Dunning et al., 2002). Figure 5 illustrates a footslope terrace at Yaxnohcah where organic clay soil harvested from a nearby seasonal wetland was used to create an effective planting surface after colluvial processes had mainly deposited rocky scree from heavily quarried supra-adjacent slopes (Dunning et al., 2017). Also at Yaxnohcah, the Maya appear to have ventured into further forms of land reclamation as exemplified by a set of box terraces constructed on gently sloping terrain that had been extensively denuded and quarried for limestone centuries before (Dunning and Carr, 2020). These enclosures were filled 
811 with soil to a depth of about $25 \mathrm{~cm}$, thus allowing for horticulture on a landscape 812 devastated by previous generations (Figure 6).

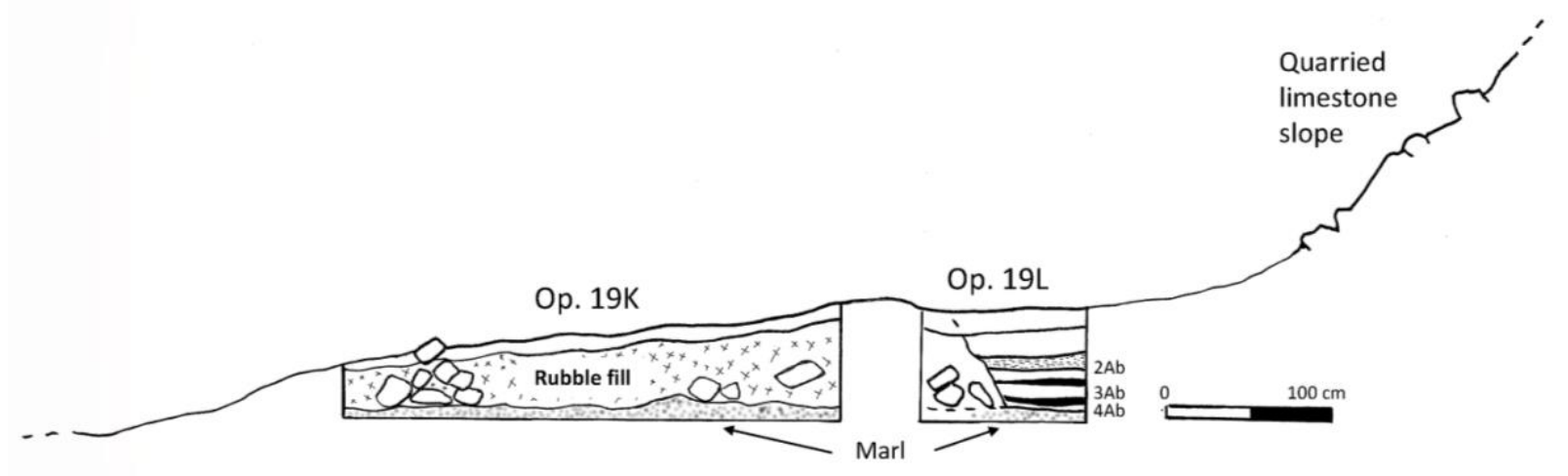

Figure 5: Cross-sectional view of a footslope terrace at Yaxnohcah, Mexico (from Dunning et al., 2017) 
a

Terrace wall

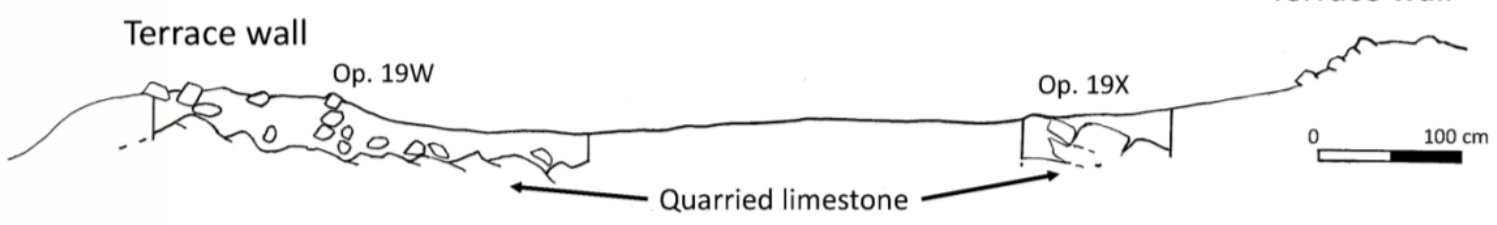

b

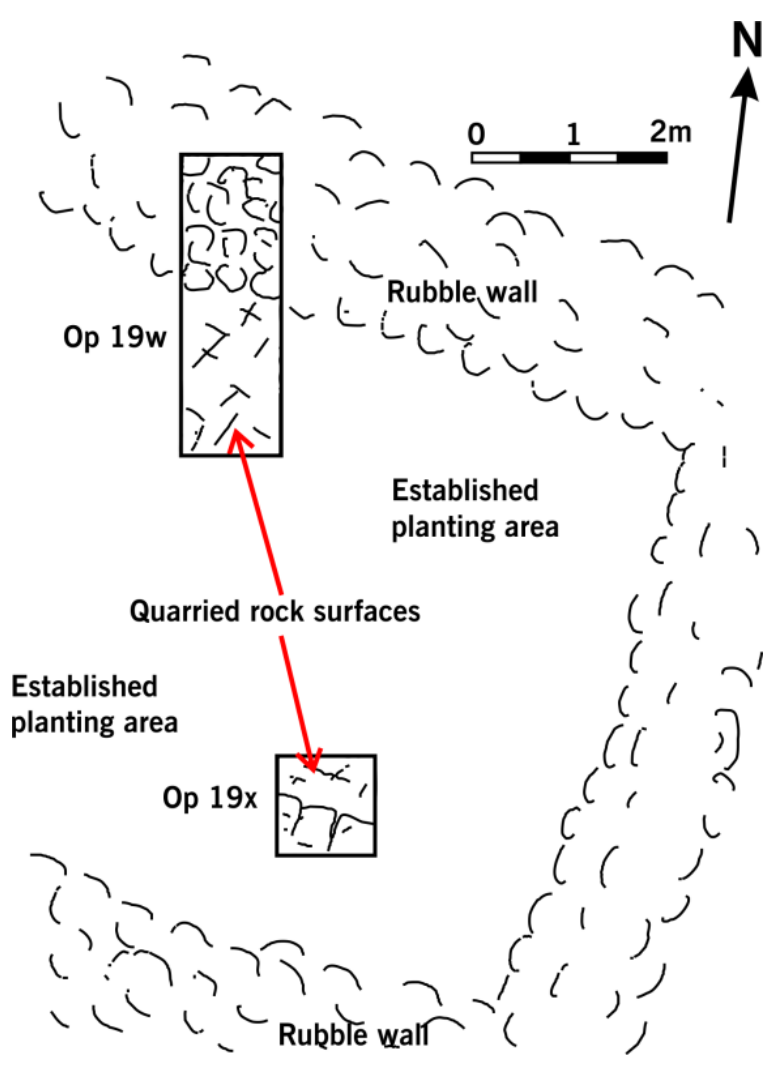

Figure 6: A set of box terraces at Yaxnohcah, Mexico (from Dunning and Carr, 2020). a) cross-sectional view; b) plan view

818 Many researchers have noted that most ancient Maya terrace systems appear to have grown accretionally, and seem to be closely associated with household-level management (Dunning and Beach, 2010; Murtha, 2015). Several examples of

821 Preclassic terracing are now known from Chan, Belize (Wyatt, 2012), Nakbé

822 (Hansen et al., 2002), and San Bartolo (Dunning and Beach, 2010). At San Bartolo, 
terraces occur in the first century CE on slopes immediately above a bajo containing a buried soil surface dating to $200-30$ BCE. This juxtaposition further suggests that terrace creation here was a reactive process. That is, the Maya came to recognize that soil erosion was occurring and needed to be controlled.

One example of proactive terracing can be found at Caracol where the most elaborate and extensive urban terracing known in the Maya lowlands was constructed over several centuries, largely in the Classic period (Chase and Chase, 1998; Chase et al., 2011). The Caracol terraces typically appear to have been planned and woven into the fabric of this large urban centre as it expanded. Nevertheless, the system seems to have been largely created and managed at the neighbourhood and household level (Murtha, 2015). Notably, Caracol is situated in extremely hilly terrain and urban agriculture would have been next to impossible without a significant landesque investment in terracing.

In parts of the Maya lowlands with an abundance of sloping terrain that lack terracing, other soil conservation strategies may have been employed to stabilize slopes. It could be speculated that the Maya have employed earthen soil berms (tablones), such as those currently used in some parts of the Guatemalan highlands, which may not have preserved after a thousand years. However, in the present day these slope protection features are chiefly built on deeper, more plastic, Andisols derived from volcanic ash, whereas most sloping upland soils in the Maya lowlands are quite shallow and stony, and seemingly less suitable (Dunning et al., 2009).

Scholars have also proffered that in some regions and urban environments the Maya may have stabilized slopes by maintaining continuous vegetative cover. This could be achieved with intensively managed gardens amidst forest cover and orchards, or 
with managed forests. For example, around Laguna Tamarindito terracing was used on some slopes, but pollen evidence from lake sediments, supported by isotopic dietary evidence from deer skeletons, indicate that steep slopes were likely left in forest cover resulting in a reduction in sedimentation from slope erosion in the Classic period (Dunning et al., 1998b). At the sprawling agro-urban landscape of Tikal, very few terraces were constructed, but several paleoenvironmental proxies suggest that a combination of permanent gardens, orchards, and managed forests were used to protect sloping land in the Classic period city after severe Preclassic erosion (Lentz et al., 2014; Dunning et al., 2015). However, a number of catenas in northwestern Belize indicate that Preclassic erosion stripped slopes of soil cover, reducing the stock of soils, which diminished sedimentation and prevented terrace investment in the Classic (Beach et al., 2018). In the more northerly lowland areas, soil cover on steep slopes was likely skeletal to begin with. The scarcity of terracing in places such as the Puuc Hills may be the result of a preponderance of steep slopes with little soil to conserve in juxtaposition with the existence of productive soils for cultivation within adjacent valleys (Dunning and Beach, 2010).

Ultimately, population pressure is one key driver for pursuing yield increases by adopting terracing as a soil conservation measure and to serve agricultural intensification. The decision by farmers to construct or maintain terraces will have varied across time and space with agro-economic demand, as well as the adoption of alternative land management strategies (Dunning and Beach, 2010). Due to lasting traces on the landscape, terracing is probably overrepresented in discourse on ancient Maya soil conservation. More ephemeral features, such as tablones, have disappeared after a millennium of abandonment, while forest succession obscures managed tree canopy systems. Lentz et al. (2014) estimate that almost half of all 
land surrounding Tikal would have needed to remain under forest cover in order to meet the voracious appetite for wood in the Late Classic. Logically, very steeply sloped lands or depressions with poor drainage, where agriculture was problematic, would have been best used for woodlots and orchards.

The archaeological evidence for soil protection and conservation strategies thus supports the interpretation that the urban Maya were increasingly aware and acquired knowledge about the necessity of maintaining and using the available stock of soil. The practice of importing soils also indicates a conscious concern with the local stock of soils and their overall proximity and accessibility in the urban environment. In the case of Caracol, there is even the implication of soil codification where knowledge about soil protection was proactively used in the planning of extensive terracing, brought on by challenging topography. When terracing is used for agricultural intensification or for specialized cultivation, the soil conservation strategy is oriented towards optimizing soil capability. Some instances of soil conservation could be seen as a beneficial side effect of requiring constant crop or tree canopy covers to provide other resources. In cities with flat topography, leaving urban areas unpaved and integrating green areas of open space (e.g., tropical forest management) would also have provided a level of soil protection and conservation. Soil care was therefore achieved through acquiring knowledge about the stock of soil in local environmental conditions and employing particular protection and conservation strategies accordingly. 


\section{Conclusions}

898

899 The forecasts of urban growth by Seto et al. (2012) imply that urban life will be confronted by an escalating paradox over the forthcoming decade. Growing urban populations will require further land conversions for housing and infrastructure, which ultimately implies there will be less land available to sustain urban life. Urban encroachment onto fertile soils is already occurring extensively (Bren d'Amour et al. 2017; Barthel et al. 2019). Growth of urban land cover will fragment the usability of soils as a resource. We embrace the suggestion that enhancing soil connectivity could provide effective solutions to mitigating this land-use paradox, countering progressive sealing of soils and incentivizing the reconfiguration of urban environments. Accepting that a degree of soil sealing in urban environments is inevitable, soil connectivity makes us recognise that it is at the edges of sealed areas where productive relations to soils start.

911 Our review of the evidence of Precolumbian lowland Maya tropical urbanism serves the purpose of elucidating the key principles of an urban way of life which developed a particularly strong practice of soil-society connectivity. The evidence demonstrates three principal ways in which Maya urban life is entangled with their soils. First, in Maya urban design, we note a pattern of land-use subdivisions in which the availability, proximity, and accessibility of unbuilt and unpaved open space is deliberately preserved, enabling the urban population to engage in nurturing soils. Crucially, making variegated 'space for soils' generates opportunities to connect with them. Second, geoarchaeological evidence of lowland urban centres demonstrates the presence of soils which stand, both in terms of thickness and geochemical

921 properties, in clear contrast to what would be expected from residual soils. We have 
presented evidence indicating that Maya urban populations actively engaged in 'contributing to soils' both through unintentional soil enhancement practices, and through more purposeful discard, mulching, and other forms of enrichment behaviours. Integrating soil formation techniques into everyday urban life would have inevitably reinforced Maya soil connectivity. Third, we have presented strong evidence that soil protection and conservation strategies formed a key characteristic of lowland Maya tropical urban life. By 'caring for soils', the Maya exhibit their awareness and knowledge about the need to maintain soil resources and, in particular, their proximity and accessibility in the urban environment.

When we appreciate that maintaining the fundamental services that soils provide depends on applying knowledge and providing opportunities to engage the urban population with soils, the Maya tropical urban landscapes furnish us with evidence on how essential constituents of such urban life play out in practice. Recognising that responding to the challenge of urban soil security requires urban design and encounter and directly engage with soils in urban life.

In accordance with the third route, our pervasive and urgent task is to foreground the availability of, and the proximity and accessibility to, soils in the urban environment. This can be achieved through realising physical changes to urban spatial design and configurations with a soil-minded awareness and attitude, facilitated by location specific soil codification in planning, policy, and design practices. The intrinsic need 
947 to stimulate soil connectivity is at the heart of this urban design challenge. Bringing 948 soils and their services back into the sights and minds of urban inhabitants going 949 about their everyday routines will inevitably encourage soil-conscious developmental 950 decisions. Prioritizing urban planning strategies which promote and enhance soil 951 connectivity could avoid patterns of urban growth that are detrimental to soil 952 properties and soil functioning. We believe a first step towards such strategies is to 953 translate our insights on lowland Maya tropical urbanism into high-order questions 954 regarding urban soils when considering urban development. Table 1 formulates the 955 high-order questions that immediately result from the Maya urban principles for 956 stimulating soil connectivity we have identified through reviewing archaeological 957 evidence. The structural consideration of these questions would aim to inspire 958 regionally appropriate ways for urban policy and design to stimulate soil connectivity, 959 and so to address urban soil security through sustainable urban development. 
961 Table 1: Questions to be addressed in order to stimulate soil connectivity inspired by

962 Maya urban principles as identified from reviewing archaeological evidence

\begin{tabular}{|c|c|c|c|}
\hline & \multicolumn{2}{|c|}{$\begin{array}{l}\text { Principles of soil connectivity } \\
\text { based in evidence of Maya urban } \\
\text { life }\end{array}$} & $\begin{array}{l}\text { Questions to be addressed in order to stimulate soil connectivity } \\
\text { in urban environments }\end{array}$ \\
\hline \multirow{3}{*}{1} & \multirow{3}{*}{ Space for soils } & Availability & To what extent are soils available to sustain urban life and functioning? \\
\hline & & Proximity & $\begin{array}{l}\text { How close are soils to urban residents and users of urban space, and to } \\
\text { what extent does the distance between people and soils inhibit } \\
\text { everyday encounters and engagement? }\end{array}$ \\
\hline & & Accessibility & How accessible are soils for direct encounters by the urban population? \\
\hline \multirow{4}{*}{2} & \multirow{3}{*}{$\begin{array}{l}\text { Contributing to } \\
\text { soils }\end{array}$} & Condition & $\begin{array}{l}\text { To what extent can the stock of soils function to sustain urban life and } \\
\text { functioning? }\end{array}$ \\
\hline & & Formation & $\begin{array}{l}\text { To what extent can soil importation and in-situ accumulation help to } \\
\text { build soils sustainably? }\end{array}$ \\
\hline & & Enrichment & To what extent can urban practices enhance soil conditions? \\
\hline & \multirow{3}{*}{ Caring for soils } & Risk & What are the risks posed to soils? \\
\hline \multirow[t]{2}{*}{3} & & Conservation & $\begin{array}{l}\text { How can conservation practices mitigate risks and protect the } \\
\text { availability and condition of soils? }\end{array}$ \\
\hline & & Proactivity & $\begin{array}{l}\text { How should soil stocks and soil conditions be further managed to } \\
\text { achieve and continue sustainable urban life and functioning? }\end{array}$ \\
\hline
\end{tabular}


963 In this paper, we have not sought to reinvent or reappraise soil connectivity as a 964 notion. Instead, we have demonstrated that urban developmental history offers valuable evidence of productive soil-society relationships in practice which further defines and substantiates the notion of soil connectivity. By studying this evidence we gain a more nuanced and context-specific insight into how urban life's intrinsic ecological relations can become focused on actively contributing to their sustainability. Crucially, the evidence permits us a vista on how the general principle of active contributions to soil management in urban life is translated into concrete designs and behaviours. While such concrete examples of designs and behaviour are directly usable in a variety of cases, translations of general soil connectivity principles will always be context-specific, changing character and implementation according to regional and cultural differences.

975 The cardinal necessity to promote healthy, functioning soils in cities is undeniable if we are to sustain contemporary urban growth and urban life. Through the lens of Precolumbian lowland Maya tropical urbanism, we have identified three spheres of influence for fostering greater soil connectivity which would operate equally if stimulated in contemporary urban environments. Therefore, we argue that Maya urbanism substantiates 'buried solutions' with immediate pertinence to the sustainable urban development challenge of soil security. Tabling archaeological insights in contemporary urban debates is a valuable step towards codifying development principles and initiatives that strengthen and exploit the ties between urban soils and urban life. 
Declaration of Interest: The authors declare that they have no known competing financial interests or personal relationships that could have appeared to influence the work reported in this paper.

Submission declaration: The authors declare that the work described here has not been published previously, it is not under consideration for publication elsewhere, and that it is approved by all authors.

992 Funding source: The paper was initiated as part of the project Pre-Columbian Tropical Urban Life: Placing the Past in Designs for Sustainable Urban Futures (TruLife), funded by an Arts \& Humanities Research Council (AHRC; UK) grant to Benjamin Vis. Daniel Evans was supported by BBSRC and NERC through a Soils 996 Training and Research Studentships (STARS) grant (no. NE/M009106/1) STARS is 997 a consortium consisting of Bangor University, the British Geological Survey, the Centre for Ecology and Hydrology, Cranfield University, the James Hutton Institute, Lancaster University, Rothamsted Research and the University of Nottingham.

1000 Nicholas Dunning's work at Yaxnohcah was part of the Proyecto Arqueológico 1001 Yaxnohcah directed by Kathryn Reese-Taylor and Armando Anaya Hernández and 1002 funded by National Science Foundation (U.S.) grant BCS-1632392.

Acknowledgements: The authors wish to thank P. Kratimenos, E. L. Barnhart, the Pakbeh Regional Economy Project, T. S. Hare, E. Lemonnier, and B. Vannière for generously granting us the permission to make use of map and image material within

1006 the manuscript. The authors are also grateful to the three anonymous reviewers. 


\section{References}

1008

1009

1010

1011

1012

1013

1014

1015

1016

1017

1018

1019

1020

1021

1022

1023

1024

1025

1026

1027

1028

Anselmetti, F. S., Ariztegui, D., Brenner, M., Hodell, D. and Rosenmeier, M. F. (2007) 'Quantification of soil erosion rates related to ancient Maya deforestation', Geology, 35, pp. 915-918.

Arnauld, M. C. (2008) 'Maya urbanization: agrarian cities in a preindustrial world', in Mastache, A. G., Cobean, R. H., García Cook, Á. and Hirth, K. G. (eds) Urbanism in Mesoamerica. Pennsylvania: Pennsylvania State University, pp. 1-36.

Arroyo-Kalin, M. (2014a) 'Anthropogenic sediments and soils: Geoarchaeology', in Smith, C. (ed.) Encyclopedia of Global Archaeology. New York: Springer, pp. 279284.

Arroyo-Kalin, M. (2014b) Amazonian dark earths: Geoarchaeology. in Smith, C. (ed.) Encyclopedia of Global Archaeology. New York: Springer, pp. 168-178.

Arroyo-Kalin, M. (2019) 'Landscaping, landscape legacies, and landesque capital in pre-Columbian Amazonia', in Isendahl, C. and Stump, D. (eds) The Oxford Handbook of Historical Ecology and Applied Archaeology. Oxford: Oxford University Press, pp. 91-109.

Ashmore, W. (1981) 'Some Issues of Method and Theory in Lowland Maya Settlement Archaeology', in Ashmore, W. (ed.) Lowland Maya Settlement Patterns. Ashmore, Albuquerque: Academic Press, pp. 37-69.

Barnhart, E. L. (2001) The Palenque Mapping Project: Settlement and Urbanism at an Ancient Maya City. PhD Thesis. University of Texas. Available at: https://repositories.lib.utexas.edu/handle/2152/10521 (Accessed: 2 August 2020). 
1029 Barnhart, E. L. (2005) Palenque’s Settlement Pattern and Social Organization 1030 Models. Available at:

1031 http://www.mayaexploration.org/pdf/PalenqueSocialOrganization__Nov2005.pdf 1032 (Accessed: 13 March 2020).

1033 Barthel, S. and Isendahl, C. (2013) 'Urban gardens, agriculture, and water 1034 management: sources of resilience for long-term food security in cities', Ecological 1035 Economics, 86, pp. 224-234.

1036 Barthel, S., Belton, S., Raymond, C. M. and Giusti, M. (2018) ‘Fostering Children’s 1037 Connection to Nature Through Authentic Situations: The Case of Saving 1038 Salamanders at School', Frontiers in Psychology, 9, doi: 10.3389/fpsyg.2018.00928.

1039 Barthel, S., Isendahl, C., Vis, B. N., Drescher, A., Evans, D. L. and van Timmeren, A. 1040 (2019) 'Global urbanisation and food production in direct competition for land: 1041 Leverage places to mitigate impacts on SDG2 and on the Earth System', The 1042 Anthropocene Review, 6(1-2), pp. 71-97.

1043 Bautista, F., Palacio Aponte, G., Quintana, P. and Zinck, J. A. (2011) 'Spatial 1044 distribution and development of soils in tropical karst areas from the Peninsula of 1045 Yucatán, Mexico', Geomorphology, 135, pp. 308-321.

1046 Beach T. (1998) 'Soil constraints on northwest Yucatán: pedo-archaeology and 1047 Maya subsistence at Chunchucmil', Geoarchaeology, 13, pp. 759-791.

1048 Beach, T. (2016) 'Morals to the Story of the 'Mayacene' from Geoarchaeology and 1049 Paleoecology', in Sanz, N., Lewis, R. C., Pulido Mata, J. and Connaughton, C. (eds) 1050 Tropical Forest Conservation: Long-term processes of human evolution, cultural 
1051

1052

1053

1054

1055

1056

1057

1058

1059

1060

1061

1062

1063

1064

1065

1066

1067

1068

1069

1070

1071

adaptations and consumption patterns. Mexico City: UNESCO Publishing, pp. 110139.

Beach, T. and Dunning, N. (1995) 'Ancient Maya Terracing and Modern

Conservation in the Peten Rainforest of Guatemala', Journal of Soil and Water Conservation, 50, pp. 138-145.

Beach, T., Luzzadder-Beach, S., Dunning, N., Hageman, J. and Lohse, J. (2002) 'Upland Agriculture in the Maya Lowlands: Ancient Maya Soil Conservation in Northwestern Belize', Geographical Review, pp. 372-397.

Beach, T., Dunning, N., Luzzadder-Beach, S., Cook, D. E. and Lohse, J. (2006) 'Impacts of the ancient Maya on soils and soil erosion in the Central Maya Lowlands', Catena, 65, pp. 166-178.

Beach, T., Luzzadder-Beach, S. and Dunning, N. (2008) 'Human and Natural Impacts on Fluvial and Karst Systems in the Maya Lowlands', Geomorphology, 101, pp. 301-331.

Beach, T., Luzzadder-Beach, S., Cook, D., Dunning, N., Kennett, D., Krause, S., Valdez, F., Trein, D. and Terry, R. (2015) 'Ancient Maya Impacts on the Earth's Surface: An Early Holocene Analogue', Quaternary Science Reviews, 124, pp. 1-30.

Beach, T., Luzadder-Beach, S., Sweetwood, R. V., Farrell, P., Mazeau, D. E., and Terry, R. E. (2017) 'Soils and Agricultural Carrying Capacity', in Hutson, S. R. (ed.) Ancient Maya Commerce: Multidisciplinary Research at Chunchucmil. Boulder: University Press of Colorado, pp. 197-220. 
1072 Beach, T., Luzzadder-Beach, S., Cook, D., Krause, S., Doyle, C., Eshleman, S., 1073 Wells, G., Dunning, N., Brennan, M. L., Brokaw, N., Cortes-Rincon, M., Hammond, 1074 G., Terry, R., Trein, D. and Ward, S. (2018) 'Stability and instability on Maya 1075 Lowlands tropical hillslope soils', Geomorphology, 305, pp. 185-208.

1076

1077

1078

1079

1080

1081

1082

1083

1084

1085

1086

1087

1088

1089

1090

1091

1092

1093

Becker, M. J. (1982) 'Ancient Maya Houses and their Identification: An evaluation of architectural groups at Tikal and inferences regarding their functions', Revista española de antropología americana, 12, pp. 111-130.

Becker, M. J. (2001) 'Houselots at Tikal Guatemala: It's what's out back that counts', in Ruiz, A. C., Ponce de Leon, M. J. I. and Carmen Martinez Martinez, M. del (eds) Reconstruyendo la Ciudad Maya: El urbanismo en las sociedades antiguas. Madrid: Sociedad Española de Estudios Mayas, pp. 427-460.

Becker, M. J. (2015) 'Ancient Maya Markets: Architecture Grammar and Market Identifications', in King, E. M. (ed.) Ancient Maya Marketplace: The archaeology of transient space. Tucson: University of Arizona Press, pp. 90-110.

Bennett, J. M., McBratney, A., Field, D., Kidd, D., Stockmann, U., Liddicoat, C. and Grover, S. (2019) 'Soil Security for Australia', Sustainability, 11(12), doi: $10.3390 /$ su11123416

Blum, W. E. H. (2005) 'Functions of Soil for Society and the Environment', Reviews in Environmental Science and Biotechnology, 4, pp. 75-79.

Braswell, G. E. (2012) 'Reinterpreting the Past of the Northern Maya Lowlands', in Braswell, G. (ed.) The Ancient Maya of Mexico: Interpreting the Past of the Northern Maya Lowlands. Sheffield: Equinox Publishing, pp. 1-40. 
1094 Bren d'Amour, C., Reitsma, F., Baiocchi, G., Barthel, S., Güneralp, B., Erb, K-H., 1095 Haberl, H., Creutzig, F., and Seto, K. C. (2017) 'Future urban land expansion and 1096 implications for global croplands', Proceedings of the National Academy of Sciences 1097 114(34), pp. 8939-8944.

1098 Caballero, J. (1992) 'Maya Home Gardens: Past, Present, and Future', 1099 Etnoecológica, 1(1), pp. 35-54.

1100 Canuto, M. A., Estrada-Belli, F., Garrison, T. G., Houston, S. D., Acuña, M. J., Kováč, M., 1101 Marken, D. et al., Nondédéo, P., Auld-Thomas, L., Castanet, C., Chatelain, D., Chiriboga, C. R., Drápela, T., Lieskovský, T., Tokovinine, A., Velasquez, A., Fernández-Díaz, J-C. and 1103 Shrestha, R. (2018) 'Ancient Lowland Maya Complexity as Revealed by Airborne Laser 1104 scanning of Northern Guatemala. Science, 361, pp. 6409-6415.Chase, A. and Chase, D. 1105 (1998) 'Scale and Intensity in Classic Maya Agriculture: Terracing and Agriculture in 1106 the 'Garden City' of Caracol, Belize', Culture and Agriculture, 20, pp. 60-77.

Chase, A. F., Chase, D. Z., Weishampel, J. F., Drake, J. B., Ramesh, L., Shrestha, K., Slatton, C., Awe, J. J. and Carter, W. E. (2011) 'Airborne LiDAR Archaeology, and the Ancient Maya landscape at Caracol, Belize', Journal of Archaeological 1110 Science, 38, pp. 387-398.

1111 Chase, A. F., Reese-Taylor, K., Fernandez-Diaz, J. C. and Chase, D. Z. (2016) 1112 'Progression and Issues in the Mesoamerican Geospatial Revolution: An 1113 introduction', Advances in Archaeological Practice, 4(3), pp. 219-231.

1114 Childe, V.G. (1950) 'The Urban Revolution', Town Planning Review, 21(1), pp. 3-17. 
1115 Dahlin, B. H., Beach T., Luzzadder-Beach, S., Hixson, S., Magnoni, A., Mansell, E. 1116 and Mazeau, D. E. (2005) 'Reconstructing agricultural self-sufficiency at

1117 Chunchucmil, Yucatán, Mexico', Ancient Mesoamerica, 16, pp. 229-247.

1118 Davoudi, S., and Stead, D. (2002) 'Urban-Rural Relationships: an introduction and a 1119 brief history', Built Environment, 28(4), pp. 269-277.

1120 Douglas, P. M. J., Pagani, M., Brenner, M., Hodell, D. A., and Curtis, J. H. (2015) 1121 'Drought, agricultural adaptation, and sociopolitical collapse in the Maya Lowlands', 1122 Proceedings of the National Academy of Sciences, 112, pp. 5607-5612.

1123 Drennan, R. D. (1988) ‘Household Location and Compact versus Dispersed 1124 Settlement in Prehispanic Mesoamerica', in Wilk, R. R. and Ashmore, W. (eds) 1125 Household and Community in the Mesoamerican Past. Albuquerque: University of 1126 New Mexico Press, pp. 273-293.

1127 Dunn, R. K. and Mazzullo, S. J. (1993) 'Holocene paleocoastal reconstruction and its 1128 relationship to Marco Gonzalez, Ambergris Caye, Belize', Journal of Field 1129 Archaeology, 20, pp. 121-131.

1130 Dunning, N. P. (1992) Lords of the Hills: Ancient Maya Settlement in the Puuc 1131 Region, Yucatán, Mexico (Monographs in World Archaeology). Texas: Prehistory 1132 Press.

1133 Dunning, N. P. (2004) 'Down on the farm: Classic Maya houselots as farmsteads', in 1134 Lohse, J., and Valdez, F. (eds.) Ancient Maya Commoners. Austin, Texas: University 1135 of Texas Press, pp. 97-114. 
1136 Dunning, N. P. and Beach, T. (2000) 'Stability and instability in prehispanic Maya 1137 landscapes', in Lentz, D. L. (ed.) An Imperfect Balance: Landscape Transformations 1138 in the Precolumbian Americas. New York: Columbia University Press, pp. 179-202.

1139 Dunning, N., and Beach, T. (2003) 'Fruit of the Luum: Lowland Maya Soil Knowledge 1140 and Agricultural Practices', Mono y Conejo, 2, pp. 1-25.

1141 Dunning, N. P. and Beach, T. (2010) 'Farms and forests: spatial and temporal 1142 perspectives on ancient Maya landscapes', in Martini, I. P. and Chesworth, W. (eds), 1143 Landscapes and Societies. Berlin: Springer-Verlag, pp. 369-389.

Dunning, N. P. and Carr, C. (2020) 'Operaciones 19 y 25: Investigaciones en y alrededor del Bajo Tomatal y El Bajo Laberinto', in Hernández, A. A. and ReeseTaylor, K. (eds) Proyecto Arqueológica Yaxnohcah, Informe de la 2018 Temporada de Investigaciones. Mexico: Consejo de Arqueología del Instituto Nacional de Antropología e Historia, pp. 107-125.

Dunning, N., Beach, T. and Rue, D. (1997) 'The Paleoecology and Ancient 1150 1151 Settlement of the Petexbatun Region, Guatemala', Ancient Mesoamerica, 8, pp. 255266.

1152 Dunning, N., Beach, T., Farrell, P. and Luzzadder-Beach, S. (1998a) 'Prehispanic 1153 Agricultural and Adaptive Regions in the Maya Lowlands', Culture and Agriculture, 1154 20, pp. 87-101.

1155 Dunning, N., Rue, D., Beach, T., Covich, A. and Traverse, A. (1998b) 'Human 1156 Environment Interactions in a Tropical Watershed: The Paleoecology of Laguna 1157 Tamarindito, Guatemala', Journal of Field Archaeology, 25, pp. 139-151. 
Dunning, N., Luzzadder-Beach, S., Beach, T., Jones, J. G., Scarborough, V. and Culbert, T. P. (2002) 'Arising from the Bajos: The Evolution of a Neotropical Landscape and the Rise of Maya Civilization', Annals of the Association of American 1161 Geographers, 92, pp. 267-283.

1162 Dunning, N. P., Beach, T., Luzzadder-Beach, S. and Jones, J. G. (2009) 'Creating a stable landscape: soil conservation among the ancient Maya', in Fisher, C., Hill, B., 1164 and Feinman, G. (eds) The Archaeology of Environmental Change: Socionatural 1165 Legacies of Degradation and Resilience. Tempe: University of Arizona Press, pp. 851166 105.

Dunning, N., Griffin, R., Jones, J., Terry, R., Larsen, Z. and Carr, C. (2015) 'Life on the Edge: Tikal in a Bajo Landscape', in Lentz, D., Dunning, N. and Scarborough, V. (eds) Tikal: Paleoecology of an Ancient Maya City. Cambridge: Cambridge University Press, pp. 95-123.

Dunning, N. P., Hernández, A. A., Haggard, A. and Carr, C. (2017) 'Investigaciones en y alrededor del ReservoRío Brisa', in Hernández, A. A. and Reese-Taylor, K. R. (eds) Proyecto Arqueológica Yaxnohcah, Informe de la 2016 Temporada de Investigaciones. Mexico: Consejo de Arqueología del Instituto Nacional de Antropología e Historia, pp. 93-122.

Dunning, N., Beach, T., Graham, E., Lentz, D., and Luzzadder-Beach, S. (2018) 'Maize, Manioc, Mamay, and More: Precolumbian Lowland Maya Agriculture', in Reid, B. (ed.) The Archaeology of Caribbean and Circum-Caribbean Farmers (5000 $B C-A D 1500)$. New York: Routledge, pp. 329-352. 
1180 Dunning, N. P., Hernández, A. A., Beach, T., Carr, C., Griffin, R., Jones, J., Lentz, 1181 D., Beach, S. L., Reese-Taylor, K. and Šprajc, I. (2019) 'Margin for Error:

1182 Anthropogenic Geomorphology of Bajo Edges in the Maya Lowlands', 1183 Geomorphology, 331, pp. 127-145.

1184 Eaton, J. D. (1975) 'Ancient Agricultural Farmsteads in the Río Bec Region of 1185 Yucatán', Contributions of the University of California Archaeological Research 1186 Facility, 27, pp. 56-82.

1187 Eberl, M., Álvarez, M. and Terry, R. E. (2012) 'Chemical Signatures of Middens at a 1188 Late Classic Maya Residential Complex, Guatemala', Geoarchaeology, 27, pp. 4261189440.

1190 Emery, K. F. (2017) 'Zooarchaeology of the Maya', in Albarella, U., Russ, H., 1191 Vickers, K. and Viner-Daniels, S. (eds) The Oxford Handbook of Zooarchaeology. 1192 Oxford: Oxford University Press, doi: 0.1093/oxfordhb/9780199686476.013.42 1193 FAO (2015) Status of the World's Soil Resources: Technical Summary. Rome: FAO. 1194 Fedick, S. and Morrison, B. (2004) 'Ancient use and manipulation of landscape in the 1195 Yalahau region of the northern Maya lowlands', Agriculture and Human Values, 21, 1196 pp. 207-219.

1197 Ferrara, A., Salvati, L., Sabbi, A. and Colantoni, A. (2014) 'Soil resources, land cover 1198 changes and rural areas: towards a spatial mismatch?', Science of the Total 1199 Environment, 478, pp. 116-122.

1200 Fletcher, L. A. (1983) 'Coba and Mayapan: a comparison of solares, household 1201 variation, socio-political organization, and land tenure', in Fletcher, L. A., Kintz, E. R., 
1202 Folan, W. J. and Fletcher, L. (eds) Coba: A Classic Maya Metropolis. London:

1203 Academic Press, pp. 121-131.

1204 Fletcher, L. A. and Kintz, E. R. (1983) 'Solares, kitchen gardens, and social status at 1205 Coba', in Fletcher, L. A., Kintz, E. R., Folan, W. J. and Fletcher, L. (eds) Coba: A 1206 Classic Maya Metropolis. London: Academic Press, pp. 103-119.

1207 Fletcher, R. J. (2009) 'Low-Density, Agrarian-Based Urbanism: A comparative view', 1208 Insights, 2(4), pp. 1-19.

1209 Garrison, T. and Dunning, N. (2009) 'Settlement, Environment, and Politics in the 1210 San Bartolo - Xultun Territory, El Peten, Guatemala', Latin American Antiquity, 20, 1211 pp. 525-552.

1212 Gifford, R. and Sussman, R. (2012) 'Environmental Attitudes', in Clayton, S. D. (ed.) 1213 The Oxford Handbook of Environmental and Conservation Psychology. Oxford:

1214 Oxford University Press, pp. 65-80.

1215 Gischler, E. and Hudson, J. J. (2004) 'Holocene development of the Belize barrier 1216 reef', Sedimentary Geology, 164, pp. 223-236.

1217 Glaser, B. and Birk, J. J. (2012) 'State of the scientific knowledge on properties and 1218 genesis of Anthropogenic Dark Earths in Central Amazonia (Terra Preta de Índio), 1219 Geochimica and Cosmochimica Acta, 82, pp. 32-51.

1220 Glaser, B. and Woods, W. I. (2004). Amazonian Dark Earths: Explorations in Space 1221 and Time. Berlin: Springer-Verlag. 
1222 Graham, E. (1996) 'Maya cities and the character of a tropical urbanism', in Sinclair, P. (ed.) The Development of Urbanism from a Global Perspective. Uppsala: Uppsala University, pp. 1-45.

Graham, E. (1998) 'Metaphor and Metamorphism: Some Thoughts on Environmental MetaHistory', in Balée, W. (ed.) Advances in Historical Ecology. New York: Columbia University Press, pp. 199-137.

Graham, E. (1999a) 'Farming the Built Environment', in Koc, M., MacRae, R., Mougeot, L. J. A. and Welsh, J. (eds) For Hunger-Proof Cities: Sustainable Urban Food Systems. Ottawa: International Development Research Centre (IDRC), pp. 150-154.

Graham, E. (1999b) 'Stone Cities, Green Cities', in Bacus, E. A. and Lucero, L. J. (eds) Complex Polities in the Ancient Tropical World. Arlington, Virginia: Archaeological Papers of the American Anthropological Association, pp 185-194.

1235 Graham, E. (2006) 'A Neotropical Framework for Terra Preta', in Balée, W. and 1236 Erickson, C. (eds) Time \& Complexity in Historical Ecology. New York: Columbia 1237 University Press, pp. 57-86.

Graham, E. and Isendahl, C. (2018) 'Neotropical cities as agro-urban landscapes', in Ekblom, A., Isendahl, C. and Lindholm, K-J. (eds) The Resilience of Heritage: Cultivating a Future of the Past. Uppsala, Sweden: Uppsala University, pp. 165-180.

1241 Graham, E., Macphail, R., Turner, S., Crowther, J., Stegemann, J., Arroyo-Kalin, M., 1242 Duncan, L., Whittet, R., Rosique, C., Austin, P. (2017) 'The Marco Gonzalez Maya site, Ambergris Caye, Belize: Assessing the impact of human activities by examining diachronic processes at the local scale', Quaternary International, 437, pp. 115-142. 
1245 Graham, E., Evans, D. L. and Duncan, L. (2020) 'A Waste of Time', in Allon, F., 1246 Barcan, R. and Eddison-Cogan, K. (eds) The Temporalities of Waste: Out of Sight, 1247 Out of Time. Abingdon: Routledge, pp. 151-166.Hansen. R. D. (1998) 'Continuity 1248 and Disjunction: Preclassic Antecedents of Classic Maya Architecture', in Houston, 1249 S. D. (ed.) Function and Meaning in Classic Maya Architecture. Washington, D. C.: 1250 Dumbarton Oaks, pp. 49-122. Hansen, R.D., Bozarth, S., Jacob, J., Wahl, D. and Schreiner, T. (2002) 'Climatic and environmental variability in the rise of Maya Civilization', Ancient Mesoamerica, 13, 1253 pp. 273-295. Hare, T. S., Masson, M. A. and Russell, B. W. (2014) 'High- Density LiDAR Mapping of the Ancient City of Mayapán', Remote Sensing, 6(9), pp. 9064-9085. Hawkins, G. (2006) The Ethics of Waste: How we relate to rubbish. Lanham: Rowan and Littlefield.

Hirth, K. G. (2003) 'The Altepetl and Urban Structure in Prehispanic Mesoamerica', in Sanders, W. T., Mastache, A. G. and Cobean, R. H. (eds) Urbanism in Mesoamerica. Pennsylvania: Instituto Nacional de Antropología e Historia, and the Pennsylvania State University, pp. 57-84.

Holliday, V. T. and Gartner, W. G. (2007) 'Soil Phosphorus and Archaeology: A 1263 Review and Comparison of Methods', Journal of Archaeological Science, 34, pp. 1264 301-333.

1265 Hutson, S. R., Magnoni, A., and Stanton, T. W. (2004) 'House rules? The practice of 1266 social organization in classic period Chunchucmil, Yucatán, Mexico', Ancient 
Hutson, S. R., Stanton, T. W., Magnoni, A., Terry, R. and Craner, J. (2007) 'Beyond the Buildings: Formation processes of ancient Maya houselots and methods for the study of non-architectural space', Journal of Anthropological Archaeology, 26, pp. $442-473$.

Inomata, T., Triadan, D., Aoyama, K., Castillo, V., and Yonenobu, H. (2013) 'Early Ceremonial Constructions at Ceibal, Guatemala, and the Origins of Lowland Maya Civilization', Science, 340(6131), pp. 467-471.

Inomata, T., Triadan, D., Vázquez López, V. A., Fernandez-Diaz, J. C., Omori, T., Bauer, M. B. M., Hernández, M. G., Beach, T., Cagnato, C., Aoyama, K. and Nasu, H. (2020) 'Monumental architecture at Aguada Fénix and the rise of Maya civilization', Nature, 582, pp. 530-533.

Isendahl, C. (2002) Common Knowledge: lowland Maya urban farming at Xuch. PhD thesis. Uppsala University. Available at: http://www.divaportal.org/smash/record.jsf?pid=diva2\%3A161573\&dswid=-615 (Accessed: 5 April 2020).

Isendahl, C. (2010) 'Greening the Ancient City: The Agro-Urban Landscapes of the Pre-Hispanic Maya', in Sinclair, P., Nordquist, G., Herschend, F. and Isendahl, C. (eds) The Urban Mind: Cultural and Environmental Dynamics, Global Studies in Archaeology. Uppsala: Uppsala University, pp. 527-552.

Isendahl, C. (2012) 'Agro-urban Landscapes: The example of Maya lowland cities', Antiquity, 86(334), pp. 1112-1125.

Isendahl, C. and Barthel, S. (2018) 'Archaeology, history, and urban food security: Integrating cross-cultural and long-term perspectives', in Zeunert, J. and Waterman, 
1291 T. (eds) Routledge Handbook of Landscape and Food. London: Routledge, pp. 611292 72.

Isendahl, C., Dunning, N. P., Sabloff, J. A. (2014) 'Growth and Decline in Classic Maya Puuc Political Economies', Archaeological Papers of the American Anthropological Association, 24, pp. 43-55.

Johnston, K. J. (2004) '"Invisible" Maya: Minimally Mounded Residential Settlement

1297 at Itzán, Petén, Guatemala', Latin American Antiquity, 15(2), pp. 145-175.

Kawa, N. C., Ding, Y., Kingsbury, J., Goldberg, K., Lipschitz, F., Scherer, M., and 1299 Bonkiye, F. (2019) 'Night Soil: Origins, Discontinuities, and Opportunities for Bridging the Metabolic Rift', Ethnobiology Letters, 10(1), pp. 40-49.

Kepecs, S. and Boucher, S. (1996) 'The Prehispanic Cultivation of Rejolladas and Stone-lands: New Evidence from Northeast Yucatán', in Fedick, S. L. (ed.) The Managed Mosaic: Ancient Maya Agriculture and Resource Use. Salt Lake City:

1304 University of Utah Press, pp. 69-91.

Killion, T. W., Sabloff, J. A., Tourtellot, G. and Dunning, N. P. (1989) 'Intensive Surface Collection of Residential Clusters at Terminal Classic Sayil, Yucatán, Mexico', Journal of Field Archaeology, 16(3), pp. 273-294.

Kintz, E. R. (1990) Life under the tropical canopy: Tradition and change among the Yucatec Maya. Austin, Texas: McDougal Publishing.

Lehmann, J., da Silva Jr, J. P., Steiner, C., Nehls, T., Glaser, B. and Zech, W. (2003)

'Nutrient availability and leaching in an archaeological Anthrosol and a Ferralsol of 1312 the central Amazon basin: fertilizer, manure and charcoal amendments', Plant and Soil, 249, pp. 343-357. 
1314

1315

1316

1317

1318

1319

1320

1321

1322

1323

1324

1325

1326

1327

1328

1329

1330

1331

1332

1333

1334

Lemonnier, E. and Vannière, B. (2013) 'Agrarian features, farmsteads and

homesteads in the Río Bec nuclear zone (Mexico)', Ancient Mesoamerica, 24(2), pp. 397-413.

Lentz, D. L., Dunning, N. P., Scarborough, V., Magee, K., Thompson, K., Weaver, E., Carr, C., Terry, R., Islebe, G., Tankersley, K., Grazioso, L., Jones, J., Buttles, P., Valdez, F. and Ramos, C. (2014) 'Forests, Fields, and the Edge of Sustainability at the Late Classic Maya City of Tikal', Proceedings of the National Academy of Sciences, 111, pp. 18513-18518.

Liendo Stuardo, R. (2002) The Organization of Agricultural Production at a Maya Center: Settlement Patterns in the Palenque Region, Chiapas, Mexico. Unpublished Doctoral Dissertation. University of Pittsburgh.

Lundell, C. L. (1938) 'Plants probably utilized by the Old Empire Maya of Peten and adjacent lowlands', Papers of the Michigan Academy of Science, Arts, and Letters, 24, pp. 37-56.

Macphail, R. I., Graham, E., Crowther, J. and Turner, S. (2017) ‘Marco Gonzalez, Ambergris Caye, Belize: a geoarchaeological record of ground raising associated with surface soil formation and the presence of a Dark Earth', Journal of Archaeological Science, 77, pp. 35-51.

Magnoni, A., Hutson, S. and Dahlin, B. (2012) 'Living in the City: Settlement patterns and the urban experience at Classic period Chunchucmil, Yucatán, Mexico', Ancient Mesoamerica, 23(2), pp. 313-343.

Magnoni, A., Stanton, T. W. and Hutson, S. R. (2014) 'The Importance of Place and Memory in the Maya Past: The Variable Appropriation of Ancient Settlement at 
1337 Chunchucmil and Yaxuná, Yucatán, during the Terminal Classic', in Stanton, T. W. 1338 (ed.) The Archaeology of Yucatán. Oxford: Archaeopress, pp. 457-466.

1339

1340

1341

1342

1343

1344

1345

1346

1347

1348

1349

1350

1351

1352

1353

1354

1355

1356

1357

1358

Masson, M. A. and Lope, C. P. (2008) 'Animal use at the Postclassic Maya center of Mayapán', Quaternary International, 191, pp. 170-183. McBratney, A., Field, D. J. and

Koch, A. (2014) 'The dimensions of soil security', Geoderma, 212, pp. 203-213.

Miller, S., Magnoni, A., Ardren, T. and Stanton, T. (2018) 'Coba’s Periphery and Rethinking Site Boundaries', The $82^{\text {nd }}$ Annual Meeting of the Society for American

Archaeology. Vancouver, B.C., 29 - 2 April, Available at:

https://core.tdar.org/document/444298/cobas-periphery-and-rethinking-siteboundaries (Accessed: 15 March 2020).

Murtha, T. (2015) 'Negotiated Landscapes: Comparative Regional Spatial Organization of Tikal and Caracol', in Marken, D. B. and Fitzsimmons, J. (eds) Classic Maya Polities of the Southern Lowlands. Boulder: University of Colorado Press, pp. 75-98.

Nigh, R. and Diemont, S. A. W. (2013) 'The Maya milpa: fire and the legacy of living soil', Frontiers in Ecology and the Environment, 11(1), doi: 10.1890/120344

Niu, L., Jia, P., Li, S., Kuang, J., He, Z., Zhou, W., Liao, B., Shu, W. and Li, J. (2015) 'Slash-and-char: An ancient agricultural technique holds new promise for management of soils contaminated by $\mathrm{Cd}, \mathrm{Pb}$ and Zn', Environment Pollution, 205, pp. 333-339.

Nondédéo, P. M., Arnauld, C. and Michelet, D. (2013) ‘Río Bec Settlement Patterns and Local Sociopolitical Organization', Ancient Mesoamerica, 24, pp. 373-396. 
1359 Peiró Vitoria, A. (2015) La Estructura Urbana de las Ciudades Mayas del Período 1360 Clásico, Catálogo de Cartografía Normalizada para el Estudio de las Ciudades Mayas del Período Clásico. PhD thesis. Available at: https://riunet.upv.es/handle/10251/61628 (Accessed: 22 December 2020).

1363 Pendergast, D. M. (1981) 'Lamanai, Belize: Summary of Excavation Results, 19741364 1980', Journal of Field Archaeology, 8(1), pp. 29-53.

1365 Prokop, G., Jobstmann, H. and Schönbauer, A. (2011) Overview of best practices for 1366 limiting soil sealing or mitigating its effects in EU-27. Available at: https://ec.europa.eu/environment/archives/soil/pdf/sealing/Soil\%20sealing\%201368 \%20Final\%20Report.pdf (Accessed: 2 August 2020).

Pugh, T. W. and Rice, P. M. (2017) 'Early urban planning, spatial strategies, and the Maya gridded city of Nixtun-Ch'ich', Petén, Guatemala', Current Anthropology, 58(5), pp. 576-603.

Rawlins, B. G., Harris, J., Price, S. and Bartlett, M. (2013) 'A review of climate change impacts on urban soil functions with examples and policy insights from 1374 England, UK', Soil Use and Management, 31, pp. 46-61.

Reese-Taylor, K. and Walker, D. S. (2002) 'The passage of the Late Preclassic into the Early Classic', in Masson, M. and Freidel, D. A. (eds) Ancient Maya Political 1377 Economies. Walnut Creek, California: Altamira Press, pp. 87-122.

1378 Rice, D. S. (1993) ‘Eighth Century Physical Geography, Environment, and Natural 1379 Resources in the Maya Lowlands', in Sabloff, J. A. and Henderson, J. S. (eds) 1380 Lowland Maya Societies in the Eighth Century A.D. Washington, D.C.: Dumbarton 1381 Oaks Pub Service, pp. 11-63. 
1382 Robin, C. (2002) 'Outside of Houses: The practices of everyday life at Chan Nòohol, 1383 Belize', Journal of Social Archaeology, 2(2), pp. 245-268.

Sabloff, J. A. (2007) 'It depends on how we look at things: New perspectives on the 1385 Postclassic period in the northern Maya lowlands', Proceedings of the American 1386 Philosophical Society, 151(1), pp. 11-26.

Seto, K. C., Güneralp, B. and Hutyra, L. R. (2012) ‘Global forecasts of urban expansion to 2030 and direct impacts on biodiversity and carbon pools', Proceedings of the National Academy of Sciences, 109(40), pp. 16083-16088.

Sharer, R. J. and Traxler, L. P. (2006) The Ancient Maya. Stanford, California: Stanford University Press.

Shaw, J. M. (2001) 'Maya Sacbeob: Form and Function', Ancient Mesoamerica, 1393 12(2), pp. 261-272.

Shaw, J. M. (2008) White Roads of the Yucatan: Changing Social Landscapes of the 1395 Yucatec Maya. Arizona: University of Arizona Press.

Simon, D. and Adam-Bradford, A. (2016) 'Archaeology and contemporary dynamics for more sustainable, resilient cities in the peri-urban interface', in Maheshwari, B., 1398 Singh, V. P. and Thoradeniya, B. (eds) Balanced Urban Development: Options and 1399 Strategies for Liveable Cities. Berlin: Springer, pp. 57-83.

1400 Slotten, V., Lentz, D. and Sheets, P. (2020) 'Landscape management and 1401 polyculture in the ancient gardens and fields at Joya de Cerén, El Salvador', Journal 1402 of Anthropological Archaeology, 59, doi: 10.1016/j.jaa.2020.101191. 
1403 Smith, M. E., Ur, J. and Feinman, G. M. (2014) 'Jane Jacobs' 'Cities First' Model and 1404 Archaeological Reality', International Journal of Urban and Regional Research, 38(4), doi: 10.1111/1468-2427.12138.

1406 Smyth, M. P., Dore, C. D. and Dunning, N. P. (1995) 'Interpreting Prehistoric 1407 Settlement Patterns: Lessons from the Maya Center of Sayil, Yucatán', Journal of 1408 Field Archaeology, 22(3), pp. 321-347.

1409 Soga, M. and Gaston, K. J. (2016) 'Extinction of experience: the loss of humannature interactions', Frontiers in Ecology and the Environment, 14(2), pp. 94-101.

1411 Steiner, C., Teixeira, W. G. and Zech, W. (2004) 'Slash and Char: An Alternative to 1412 Slash and Burn Practiced in the Amazon Basin', in Glaser, B. and Woods, W. I. (eds) 1413 Amazonian Dark Earths: Explorations in Space and Time. Berlin: Springer-Verlag, 1414 pp. 183-193.

1415 Strange, R. (2015) 'Feeding more than 9 billion by 2050: challenges and 1416 opportunities', Food Security, 7, pp. 177-178.

1417 Stuart, G. E., Scheffler, J. C., Kurjack, E. B. and Cottier, J. W. (1979) 'Maps of the 1418 Ruins of Dzibilchaltun'. Available at: https://mariecom.wp.tulane.edu/product/map-of1419 the-ruins-of-dzibilchaltun/ (Accessed: 22 December 2020).

1420 Tankersley, K., Dunning, N. P., Scarborough, V., Lentz, D. and Carr, C. (2016) 1421 'Catastrophic Volcanism, Climate Change, and Ancient Urbanism in the Maya 1422 Lowlands', Journal of Archaeological Science: Reports, 5, pp. 465-470.

1423 Tourtellot, G., Sabloff, J. A., Smyth, M. P., Van Whitley, L., Walling, S. T., Negrón, T. 1424 G., Alvarez, C. P., Andrews, G. F. and Dunning, N. P. (1988) 'Mapping Community 
1425 Patterns at Sayil, Yucatán, Mexico: The 1985 Season', Journal of New World 1426 Archaeology, 7(43), pp. 1-24.

1427 Tresch, S., Moretti, M., Le Bayon, R. C., Mäder, P., Zanetta, A., Frey, D., Stehle, B., 1428 Kuhn, A., Munyangabe, A. and Fliessbach, A. (2018) 'Urban soil quality assessment 1429 - a comprehensive case study dataset of urban garden soils', Frontiers in 1430 Environmental Science, 6(136), pp. 1-5.

1431 United Nations (2015) Resolution adopted by the General Assembly on 25 1432 September 2015. Available at:

1433 https://www.un.org/en/development/desa/population/migration/generalassembly/doc 1434 s/globalcompact/A_RES_70_1_E.pdf (Accessed: 2 August 2020).

1435 Vis, B. N. (2018) Cities Made of Boundaries: Mapping Social Life in Urban Form. 1436 London: UCL Press.

1437 Vis, B. N., Evans, D. L., Isendahl, C. and Graham, E. (2020) 'Dust to Dust:

1438 Redesigning Urban Life in Healthy Soil', Air Water Environment International, 66, pp. 1439 47-55.

1440 Vrščaj, B., Poggio, L. and Marsan, F. A. (2008) 'A method for soil environmental 1441 quality evaluation for management and planning in urban areas', Landscape and 1442 Urban Planning, 88, pp. 81-94.

1443 Wagner, P. L. (1964) 'Natural vegetation of Middle America', in West, R. C. (ed.) 1444 Handbook of Middle American Indians: Natural Environment and Early Cultures. 1445 Austin, Texas: University of Texas Press, pp. 216-264. 
1446 West, R. C. (1964) 'Surface configuration and associated geology of Middle

1447 America', in West, R. C. (ed.) Handbook of Middle American Indians: Natural

1448 Environment and Early Cultures. Austin, Texas: University of Texas Press, pp. 33-

144983.

1450 White, C. D. (1999) Reconstructing Maya Diet. Salt Lake City: University of Utah 1451 Press.

1452 Wilk, R. R. and Ashmore, W. (1988) 'Household and Community in the

1453 Mesoamerican Past', in Wilk, R. R. and Ashmore, W. (eds) Household and

1454 Community in the Mesoamerican Past. Albuquerque: University of New Mexico

1455 Press, pp. 1-27.

1456 Wyatt, A. R. (2012) 'Agricultural Practices at the Chan Site: Farming and Political

1457 Economy in an Ancient Maya Community', in Robin, C. (ed.) Chan: An Ancient Maya

1458 Farming Community in Belize. Arizona: University of Arizona Press, pp. 71-88. 